This report was prepared as an account of work sponsored by an agency of the United States Government. Neither the United States Government nor any agency thereof, nor any of their employees, makes any warranty, express or implied, or assumes any legal liability or responsibility for the accuracy, completeness, or usefulness of any information, apparatus, product, or process disclosed, or represents that its use would not infringe privately owned rights. Reference herein to any specific commercial product, process, or service by trade name, trademark, manufacturer, or otherwise does not necessarily constitute or imply its endorsement, recommendation, or favoring by the United States Government or any agency thereof. The views and opinions of authors expressed herein do not necessarily state or reflect those of the United States Government or any agency thereof.

\title{
Zinc(II) Oxide Solubility and Phase Behavior in Aqueous Sodium Phosphate Solutions at Elevated Temperatures
}

S. E. Ziemniak

M. E. Jones

K. E. S. Combs

February 1990

Prepared for

The United States Department of Energy

Assistant Secretary for Nuclear Energy

Deputy Assistant Secretary for Naval Reactors

Prepared by

General Electric Company

KNOLLS ATOMIC POWER LABORATORY

Schenectady, New York

Contract DE-AC12-76SN00052 


\section{DISCLAIMER}

This report was prepared as an account of work sponsored by an agency of the United States Government. Neither the United States Government nor any agency thereof, nor any of their employees, makes an warranty, express or implied, or assumes any legal liability or responsibility for the accuracy, completeness, or usefulness of any information, apparatus, product, or process disclosed, or represents that its use would not infringe privately owned rights. Reference herein to any specific commercial product, process, or service by trade name, trademark, manufacturer, or otherwise, does not necessarily constitute or imply its endorsement, recommendation, or favoring by the United States Government or any agency thereof. The views and opinions of authors expressed herein do not necessarily state or reflect those of the United States Government or any agency thereof. 
ABSTRACT ......................................

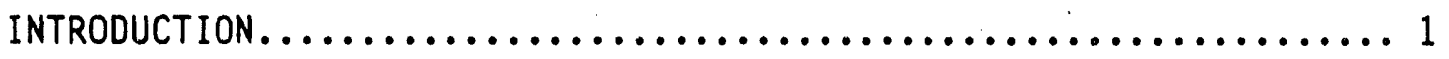

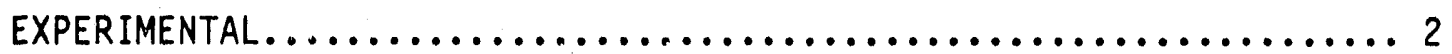

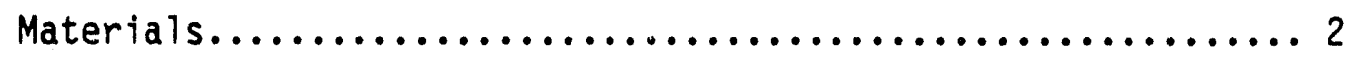

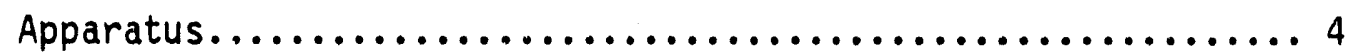

Procedures................................... 4

RESULTS...................................... 8

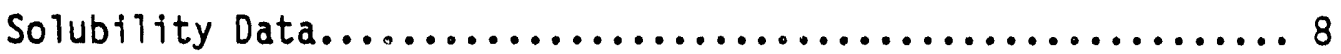

Thermodynamic Analysis......................... 8

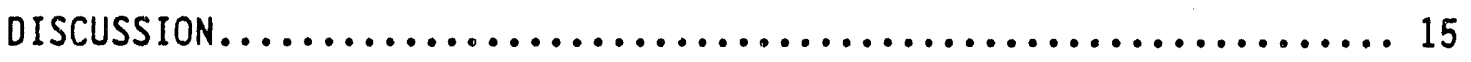

Zinc Oxide Dissolution into $\mathrm{Zn}(\mathrm{OH})_{2}(\mathrm{aq}) \ldots \ldots \ldots \ldots \ldots \ldots$

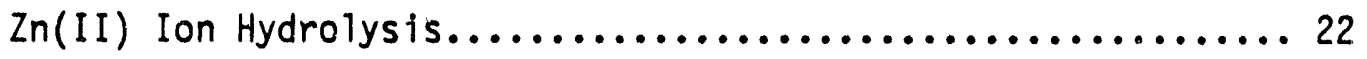

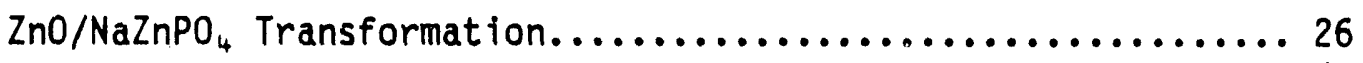

Zn(II) Ion Phosphatocomplex Formation................. 29

REFERENCES........................................ 34 


\section{ILLUSTRATIONS}

Figure

No.

Schematic of flowing autoclave system used in zinc oxide solubility investigation

2 Comparison of measured and fitted solubilities of zinc oxide in sodium phosphate solutions $(\mathrm{Na} / \mathrm{P}=2.3)$

3 Comparison of nieasured and fitted solubilities of $\mathrm{NaZnPO}_{4}$ in sodium phosphate solutions $(\mathrm{Na} / \mathrm{P}=2.3)$

4 Comparison of measured and fitted solubilities $\mathrm{NaZnPO}_{4}$ in sodium phosphate solutions (phosphate $=10.5 \mathrm{mmol} / \mathrm{kg}$ )

5 Free energy changes measured during zinc oxide dissolution

6 Comparison of free energy changes associated with $\mathrm{Zn}$ (II) ion hydrolys is reactions

7 Comparison of measured and fitted solubilities of zinc oxide in sodium hydroxide solutions.

8 Standard entropies for $\mathrm{Zn}$ (II) and $\mathrm{Cu}$ (II) fons and their hydroxocomplexes

9 Predicted phase boundary for $\mathrm{ZnO} / \mathrm{NaZnPO}_{4}$ transformation in aqueous sodium phosphate solutions

10 Distribution of $\mathrm{Zn}$ (II) ion complexes present in solution at $298 \mathrm{~K}$ (top) and $560 \mathrm{~K}$ (bottom) $(\mathrm{Na} / \mathrm{P}=2.3)$

\section{TABLES}

Table

No.

Feedwater Compositions

II. Zno Bed Transformation Effects

III. Measured $\mathrm{ZnO} / \mathrm{NaZnPO}_{4}$ Solubilities in Aqueous Sodium Phosphate Solutions

IV. Dissociation Behavior of Selected Compounds

v. Thermodynamic Equilibria for Calculation of $\mathrm{ZnO} / \mathrm{NaZnPO}_{4}$ Solubilities in Alkal ine Sodium Phosphate Solutions via $\Delta G(T)=A$ - BT CTenT

VI. Thermochemical Parameters for Species in the $\mathrm{ZnO}-\mathrm{H}_{2} \mathrm{O}$ system

VII. Thermochemical Parameters for Phosphate-Based Species in the $\mathrm{ZnO}-\mathrm{Na}_{2} \mathrm{O}-\mathrm{P}_{2} \mathrm{O}_{5}-\mathrm{H}_{2} \mathrm{O}$ System 
A platinum-lined, flowing autoclave facility is used to investigate the solubility/phase behavior of zinc(II) oxide in aqueous sodium phosphate solutions at temperatures between 290 and $560 \mathrm{~K}$. ZnO solubilities are observed to increase continuously with temperature and phosphate concentration. At higher phosphate concentrations, a solid phase transformation to $\mathrm{NaZnPO}_{4}$ is observed. $\mathrm{NaZnPO}_{4}$ solubilities are retrograde with temperature.

The measured solubility behavior is examined via a $\mathrm{Zn}$ (II) ion hydrolysis/ complexing model and thermodynamic functions for the hydrolysis/complexing reaction equilibria are obtained from a leastsquares analysis of the data. The existence of two new zinc(II) ion complexes is reported for the first time: $\mathrm{Zn}(\mathrm{OH})_{2}\left(\mathrm{HPO}_{4}\right)=$ and $\mathrm{Zn}(\mathrm{OH})_{3}\left(\mathrm{H}_{2} \mathrm{PO}_{4}\right)=$. A summary of thermochemical properties for species in the systems $\mathrm{ZnO}-\mathrm{H}_{2} \mathrm{O}$ and $\mathrm{ZnO}-\mathrm{Na}_{2} \mathrm{O}-\mathrm{P}_{2} \mathrm{O}_{5}-\mathrm{H}_{2} \mathrm{O}$ is also provided. 


\section{ACKNOWLEDGEMENT}

H. J. Schermerhorn prepared the Zno used in this study;

A. N. Lord performed all X-ray diffraction analyses. 


\section{Zinc(II) Oxide Solubility and Phase Behavior in Aqueous Sodium Phosphate Solutions at Elevated Temperatures S.E. Ziemniak, M.E. Jones, K.E.S. Combs}

INTRODUCTION

Zinc is an alloying constituent of many brass and bronze components used throughout the water-steam circuit of power plants. In order to quantify the hydrothermal aspects of the zinc oxide corrosion products that are transported in such systems, a priori knowledge of zinc oxide solubility and phase behavior must be available.

Many solubility studies of $\mathrm{ZnO}$ have been performed in alkaline media at room temperature, cf. summaries provided by Baes and Mesmer ${ }^{(1)}$ or Khodakovskif and $E l k i{ }^{(2)}$, so that reliable standard free energies of formation are available for the series of hydroxocomplexes $\mathrm{Zn}(\mathrm{OH})_{n}{ }^{(2-n)}(n=2,3,4)$. An additional high-temperature Zno solubility study was performed in pure water and aqueous sodium hydroxide ${ }^{(2)}$, so that a fairly reliable solubility data base exists over a broad range of alkalinity and temperature.

With regard to solid phase stability in the $\mathrm{ZnO}-\mathrm{H}_{2} \mathrm{O}$ system, $\mathrm{ZnO}$ is known to be thermodynamically stable relative to $\varepsilon-\mathrm{Zn}(\mathrm{OH})_{2}$ at $298 \mathrm{~K}$. However, the hydrous oxide form is known to resist transformation for times long enough to permit accurate solubility measurements at room temperature ${ }^{(3)}$. As phosphate concentration and temperature increase, phosphate ion complexes of the hydrolyzed zinc(II) ion are expected to dominate over the usual zinc(II) fon hydroxocomplexes present in solution. In alkaline sodium phosphate solutions, this situation eventually leads to the precipitation of a sodium salt of the phosphato-hydroxo-zincate ion. Under these circumstances, $\mathrm{ZnO}$ is no longer 
the stable solid phase. Thilo and Schulz ${ }^{(4)}$ have already characterized $\mathrm{NaZnPO}_{4} \cdot \mathrm{H}_{2} \mathrm{O}$ as the stable sodium ion salt precipitated from aqueous $\mathrm{Na}_{2} \mathrm{HPO}_{4}$ solutions at ambient temperatures. Dehydration to $\mathrm{NaZnPO}_{4}$ is expected at higher temperatures $\left({ }^{4}, 5\right)$.

The present work was undertaken to establish the experimental and theoretical bases for determining solubilities (and stabilities) of a zinc oxide corrosion product $(\mathrm{ZnO})$ in aqueous sodium phosphate solutions at elevated temperatures. Our method involved pumping sodium orthophosphate solutions of known compositions through a ZnO bed and analyzing the emerging solution for $\mathrm{Zn}$. Based on these solubility measurements, thermochemical properties were established for the following $\mathrm{Zn}$ (II) anionic complexes: $\mathrm{Zn}(\mathrm{OH})_{2}(\mathrm{aq}), \mathrm{Zn}(\mathrm{OH})_{3}^{-}, \mathrm{Zn}(\mathrm{OH})_{4}^{=}, \mathrm{Zn}(\mathrm{OH})_{2}\left(\mathrm{HPO}_{4}\right)^{=}$, and $\mathrm{Zn}(\mathrm{OH})_{3}\left(\mathrm{H}_{2} \mathrm{PO}_{4}\right)=$. Similar properties were also established for $\mathrm{NaZnPO}_{4}$ based on a thermodynamic analysis of the $\mathrm{ZnO} / \mathrm{NaZnPO}_{4}$ solid phase transformation reaction equilibrium.

\section{EXPERIMENTAL}

\section{Materials}

Zinc oxide was prepared from "Baker Analyzed" reagent grade zinc oxide powder supplied by the J. T. Baker Chemical Company. Because the as-received powder was too fine to be retained as a packed column in a flowing autoclave system, it was transformed into larger particles by compaction followed by attrition through a 10 mesh sieve onto a 20 mesh sieve. The particles were then fired at $1473 \mathrm{~K}$ for $16 \mathrm{hr}$ in an air atmosphere and slowly sooled to room temperature. The material produced in this manner consisted of hard, irregular-shaped, pale yellow particles with dimensions of 1.3 to $2.5 \mathrm{~mm}$. The color change from white to yellow during and after sintering is a naturally 
occurring phenomenon related to a thermal shift in the electron energy absorption band to the visible region. No chemical change in the composition of zinc oxide is produced by this phenomenon.

X-ray diffraction analysis confirmed the presence of a single phase hexagonal lattice structure characteristic of zinc oxide $(a=3.2503 \pm 0.0003$ $\AA$ and $c=5.2064 \pm 0.0005 \AA)$. Emission spectroscopy found iron to be the majoi impirity: 60 ppm.

Deionized, deoxycenated water (obtained from Vapodur 607 and Amberlite IRN-150 ion-exchange resin columns) was used throughout the experimental program. This water had a resistivity $>1$ Mohm-cm and contained $<0.1 \mathrm{mg}-\mathrm{L}^{-i}$ silica. Linde commercial grade nitrogen was used to sparge dissolved oxygen to values $<0.005 \mathrm{mg}^{-1}$. Test solutions were prepared volumetricality in the feed tanks using reagent grade sodium phosphate.

After completing the final solubility run (at high temperature), flow through the solubility apparatus was terminated. The zinc oxide charge was then removed and subjected to additional characterization. Digestion in acid, followed by quantitative wet chemistry analyses revealed a $\mathrm{Zn} / \mathrm{Na} / \mathrm{P}$ atom ratio of $200 / 1 / 1$. Elemental microanalyses of fractured $\mathrm{ZnO}$ particles, performed via the energy dispersive $X$-ray (EDX) attachment to a scanning electron microscope, revealed significant $P / Z n$ ratios $(0.6)$ at the surface edges. However, the Zno particle interiors were free of phosphate. Repeat $X$-ray diffraction analyses (of powdered material) revealed no changes in Zno lattice parameters, although trace amounts of an additional phase, presumed to be $\mathrm{NaZnPO}_{4}$, were also detected. The Zno surface deposits were solubilized by a brief, roontemperature soak in dilute hydrochloric acid; analyses of the supernatant 
liquid gave $\mathrm{Na} / \mathrm{P}=1$. The above analyses indicate that a $\mathrm{NaZnPO}_{4}$ coating formed on the Zno surfaces during exposure in the solubility apparatus.

\section{Apparatus}

The solubility measurements were made using two identical flowing autoclave systems. A diagram of an individual system is shown in Figure 1. Although each system was constructed using stainless steel components, all high-temperature portions as well as the sampling lines were platinum-lined. Further details on the construction and oparation of the apparatus are contained in Reference (6). The experimental program consisted of solubility measurements conducted in deoxygenated water maintained with a one atmosphere blanket of nib, ogen cover gas. Feedwater compositions are shown in Table I.

TABLE I. Feedwater Compositions

\begin{tabular}{|c|c|c|c|c|}
\hline Run & $\begin{array}{c}\text { Phosphate, } \\
\text { mmol } / \mathrm{kg}\end{array}$ & $\mathrm{Na} / \mathrm{P}$, molar & $\mathrm{pH}$ at $298 \mathrm{~K}$ & $\begin{array}{l}\text { Conduct iyity } \\
\mu \mathrm{S}-\mathrm{cm}^{-1}\end{array}$ \\
\hline $\begin{array}{l}1 \\
2 \\
3 \\
4 \\
5 \\
6 \\
7\end{array}$ & $\begin{aligned} 0.551 & \pm 0.016 \\
1.658 & \pm 0.032 \\
3.327 & \pm 0.042 \\
10.95 & \pm 0.32 \\
53.07 & \pm 0.63 \\
10.64 & \pm 0.11 \\
10.64 & \pm 0.11\end{aligned}$ & $\begin{array}{l}2.300 \pm 0.011 \\
2.334 \pm 0.005 \\
2.328 \pm 0.007 \\
2.349 \pm 0.006 \\
2.346 \pm 0.013 \\
2.176 \pm 0.003 \\
2.810 \pm 0.008\end{array}$ & $\begin{array}{l}10.24 \pm 0.03 \\
10.68 \pm 0.05 \\
11.02 \pm 0.01 \\
11.29 \pm 0.02 \\
11.38 \pm 0.02 \\
10.98 \pm 0.03 \\
11.70 \pm 0.02\end{array}$ & $\begin{array}{c}150 \pm 3 \\
438 \pm 8 \\
805 \pm 18 \\
2375 \pm 20 \\
8375 \pm 80 \\
2090 \pm 50 \\
3090 \pm 70\end{array}$ \\
\hline
\end{tabular}

\section{Procedures}

After the system was stabilized at a desired temperature, steady-state conditions were maintained for at least $60 \mathrm{~min}$; the system flow was then diverted into the sampling system. Each sample, consisting of $\sim 240 \mathrm{~mL}$ of solution, was collected in a polyethylene bcttle containing $0.25 \mathrm{~mL}$ of redistilled concentrated nitric acid. Triplicate samples were withdrawn at each temperature. After the three samples had been collected, the temperature 


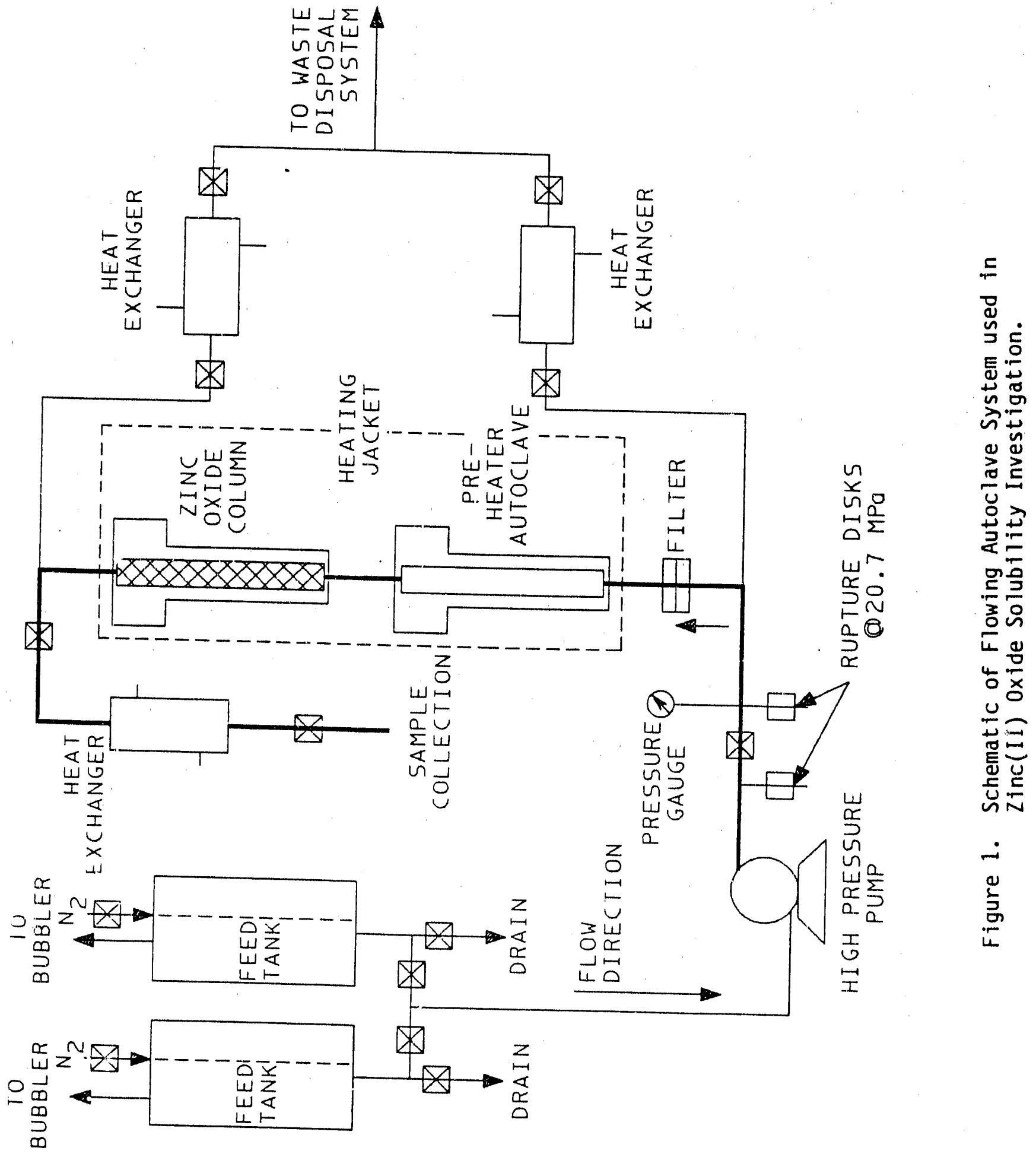


controller and Variac settings were changed to establish a new temperature. From 30 to 90 min were required to stabilize the system at the new temperature. After an additional $60 \mathrm{~min}$ or longer, the sampling procedure was repeated. This process of changing temperature, allowing time for equilibration, and sampling, continued throughout each experimental run.

Each sample was weighed and then concentrated to a volume of $10.0 \mathrm{~mL}$ in a Pyrex beaker. The resulting solution was analyzed for zinc by atomic absorption, utilizing standard techniques. A Perkin-Elmer Model 303 Atomic Absorption Spectrophotometer was used with an air-acetylene flame. A set of sodium phosphate solutions containing known amounts of zinc was run several times with each group of samples analyzed. Phosphate concentrations and sodium-to-phosphate molar ratios were determined by potentiometric titration with dilute hydrochloric acid.

The actual experimental program consisted of seveh runs (see Table I) during which the nominal temperature range 294 to $560 \mathrm{~K}$ was covered. The first two runs traversed the temperature range in three intervals: (1) increasing from 294 to $408 \mathrm{~K}$ in $14 \mathrm{~K}$ ir:crements, (2) decreasing from 533 to 422 in $28 \mathrm{~K}$ increments, and (3) increasing from 408 to $560 \mathrm{~K}$ in $28 \mathrm{~K}$ increments.

In Runs 3 to 7 a transformation of the zinc oxide bed occurred at higher temperatures. This transformation was manifested by decreases in zinc solubilities with time (at temperature) and by changes in the composition of the effluent sodium phosphate solutions. Representative data, as presented in Table II, confirmed that the bed transformation was associated with the formation of a layer of $\mathrm{NaZnPO}_{4}$ (i.e., $\mathrm{Na} / \mathrm{P}=1.0$ ) on the $\mathrm{ZnO}$ surface. Therefore, the sequence of subsequent sampling/operating events became very important, 


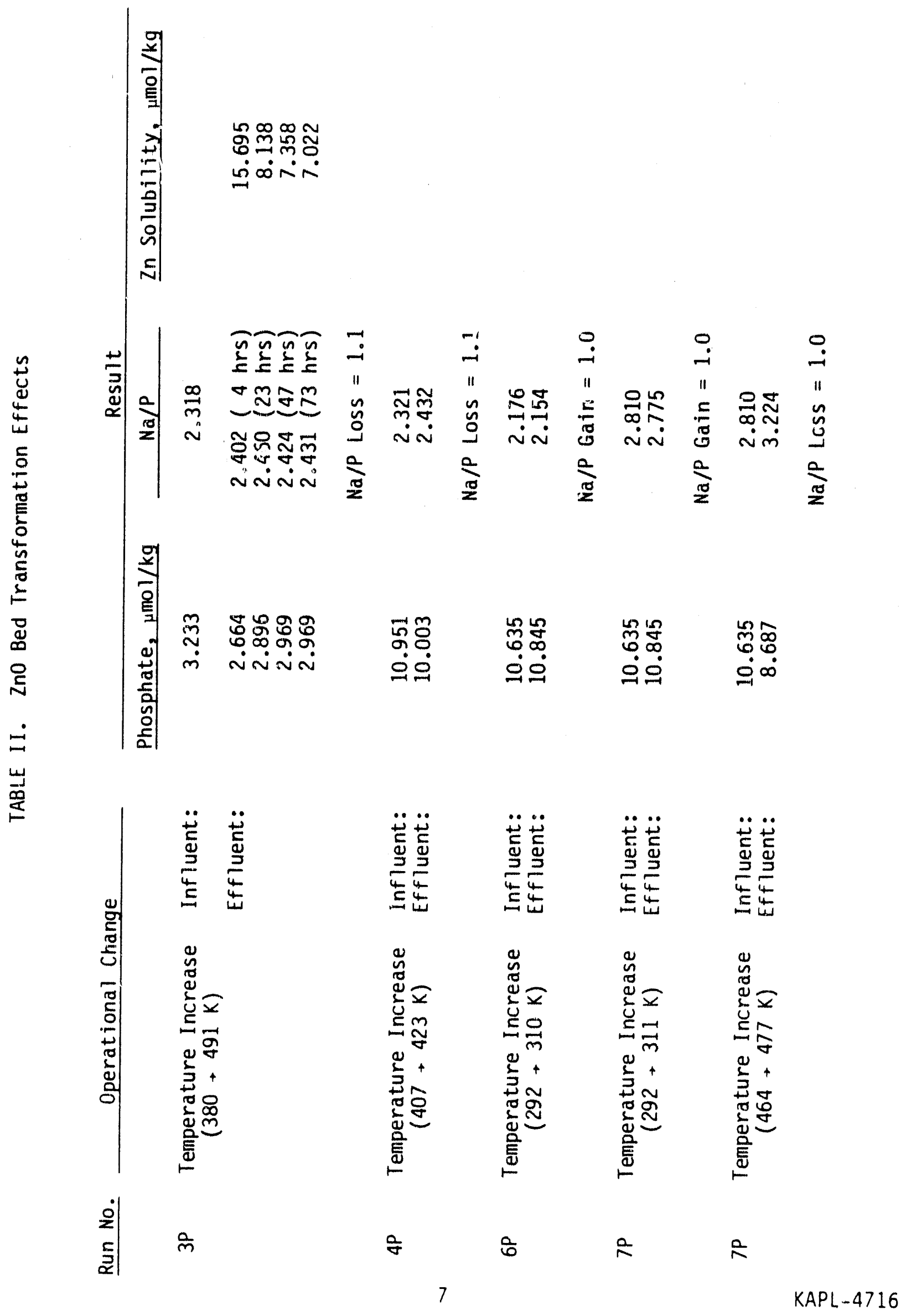


because it was necessary to ensure that zinc solubilities were being measured for the thermodynamically stable solid phase at operating conditions (i.e., $\mathrm{NaZnPO}_{4}$ ). Run 3 omitted the first $\Delta T$ interval and Runs 4 to 7 were conducted by increasing temperature from 380 to $560 \mathrm{~K}$ in $14 \mathrm{~K}$ increments. Additional (replicate) samples were withdrawn at 477,455, and $408 \mathrm{~K}$ at the end of Runs 6 and 7 .

\section{RESULTS}

Solubility Data

Results from the experimental program, in terms of m-asured zinc solubilities as a Anction of temperature, are presented in Table III. The elemental zinc concentrations represent averages of triplicate samples taken $\sim \frac{1}{2} \mathrm{hr}$ apart and are given in micromolality units, $\mu \underline{m}$ ( $\mu$ mol per kilogram of water). The small amounts of material lost in the sampling line have been neglected. The temperature value listed for a particular sample was the average of the two downstream thermocouple readings at the start and completion of sampling.

Consistent with our previous discussion, the zinc solubilities reported in Table III include only those values unaffected by bec transformation effects.

\section{Thermodynamic Analys is}

Zinc oxide is expected to solubilize in aqueous solutions via the following reaction:

$$
\mathrm{ZnO}(\mathrm{s})+2 \mathrm{H}^{+} \ddagger \mathrm{Zn}^{+2}+\mathrm{H}_{2} \mathrm{O}
$$


TABLE III. Measured $\mathrm{ZnO} / \mathrm{NaZnPO}_{4}$ Solubilities in Aqueous Sodium Phosphate Solutions

\begin{tabular}{|c|c|c|c|c|c|c|c|}
\hline \multicolumn{2}{|c|}{ Run 1} & \multicolumn{2}{|c|}{ Run 2} & \multicolumn{2}{|c|}{ Run 3} & \multicolumn{2}{|c|}{ Run 4} \\
\hline$I(K)$ & $Z n^{*}$ & $I(K)$ & $2 n^{\star}$ & $I(K)$ & $2 n^{\star}$ & $T(K)$ & $\mathrm{Zn}{ }^{\star}$ \\
\hline $\begin{array}{l}339.3 \\
352.0 \\
368.2 \\
379.8 \\
394.3 \\
407.6 \\
407.6 \\
423.7 \\
435.9 \\
449.3 \\
463.7 \\
479.3 \\
491.5 \\
505.9 \\
519.3 \\
533.2 \\
546.5 \\
561.5\end{array}$ & $\begin{array}{l}0.769 \\
0.909 \\
1.074 \\
1.201 \\
1.391 \\
1.637 \\
1.759 \\
2.096 \\
2.310 \\
2.493 \\
2.769 \\
2.968 \\
3.167 \\
3.304 \\
3.503 \\
3.549 \\
3.778 \\
3.824\end{array}$ & $\begin{array}{l}338.7 \\
352.6 \\
367.0 \\
379.3 \\
395.4 \\
407.6 \\
408.2 \\
424.8 \\
434.3 \\
449.3 \\
463.2 \\
478.7 \\
489.8 \\
504.8 \\
519.8 \\
533.2 \\
546.5 \\
560.9\end{array}$ & $\begin{array}{l}1.348 \\
1.606 \\
1.805 \\
2.035 \\
2.255 \\
2.555 \\
2.539 \\
2.998 \\
3.243 \\
3.763 \\
4.375 \\
4.911 \\
5.125 \\
5.813 \\
6.150 \\
6.578 \\
6.884 \\
7.404\end{array}$ & $\begin{array}{l}449.3 \\
478.7 \\
504.8 \\
518.2 \\
531.5 \\
547.0 \\
563.7\end{array}$ & $\begin{array}{l}5.538 \\
5.568 \\
5.308 \\
4.819 \\
4.895 \\
4.314 \\
3.641\end{array}$ & $\begin{array}{l}436.5 \\
449.3 \\
463.7 \\
477.6 \\
490.9 \\
504.8 \\
519.3 \\
532.0 \\
547.0 \\
561.5\end{array}$ & $\begin{array}{l}6.563 \\
4.803 \\
4.436 \\
4.222 \\
4.176 \\
3.901 \\
3.901 \\
3.595 \\
3.488 \\
3.121\end{array}$ \\
\hline Ru & 5 & & 6 & & 7 & & \\
\hline$I(K)$ & $2 n^{\star}$ & $I(K)$ & $2 n^{\star}$ & $I(K)$ & $2 n^{\star}$ & & \\
\hline $\begin{array}{l}379.8 \\
394.8 \\
408.2 \\
408.7 \\
422.0 \\
434.8 \\
449.3 \\
463.2 \\
478.2 \\
491.5 \\
506.5 \\
519.8 \\
532.6 \\
547.6 \\
561.5\end{array}$ & $\begin{array}{l}18.40 \\
16.29 \\
13.60 \\
14.23 \\
11.36 \\
11.14 \\
9.683 \\
8.857 \\
8.092 \\
7.557 \\
7.220 \\
7.022 \\
6.593 \\
6.287 \\
5.966\end{array}$ & $\begin{array}{l}396.5 \\
408.2 \\
408.2 \\
408.2 \\
420.9 \\
435.9 \\
449.8 \\
455.9 \\
463.7 \\
475.9 \\
477.0 \\
477.6 \\
491.5 \\
505.9 \\
519.8 \\
533.2 \\
547.0 \\
560.4\end{array}$ & $\begin{array}{l}4 ., 3 \\
3.102 \\
3.503 \\
3.335 \\
3.014 \\
2.662 \\
2.448 \\
2.356 \\
2.555 \\
2.341 \\
2.249 \\
2.555 \\
2.432 \\
2.493 \\
2.616 \\
2.371 \\
2.279 \\
2.111\end{array}$ & $\begin{array}{l}394.3 \\
408.7 \\
408.7 \\
408.7 \\
410.4 \\
420.4 \\
436.5 \\
455.4 \\
473.7 \\
474.3 \\
490.9 \\
505.4 \\
519.3 \\
533.7 \\
546.5 \\
560.4\end{array}$ & $\begin{array}{l}23.94 \\
21.20 \\
21.68 \\
22.23 \\
22.64 \\
19.67 \\
17.36 \\
13.94 \\
11.32 \\
11.20 \\
9.974 \\
8.460 \\
7.542 \\
6.593 \\
5.859 \\
5.155\end{array}$ & & \\
\hline
\end{tabular}


Furthermore, the dissolved zinc(II) ion is known to be stabilized in aqueous solutions by the formation of aquo and hydroxocomplexes. That is, the divalent zinc ion becomes surrounded by an inner hydration sheath of six water molecules with octahedral symmetry $\left.{ }^{7}\right)$. Stepwise dissociation of these complexed water molecules occurs as the pH of the solution is elevated. Thus, the overall zinc oxide dissolution reaction becomes the following sequence:

$$
\mathrm{ZnO}(\mathrm{s})+(2-n) \mathrm{H}^{+} \neq \mathrm{Zn}(\mathrm{OH})_{n}^{2-n}+(1-n) \mathrm{H}_{2} \mathrm{O} \text {, }
$$

where $n$ refers to the state of hydrolysis and may take on the values $0,1,2$, 3, or 4. Due to the cnaracteristic hydrolysis behavior of the zinc(II) ion, (cf. Reference 1) and the alkaline pH range employed during the present study, concentrations of the species corresponding to $n=0$ and 1 are expected to contribute insignificantly to the zinc oxide solubility database.

On the other hand, if the high-temperature portions of Runs 3 to 7 indeed represent an equilibrium with another solid phase in the system $\mathrm{ZnO}-\mathrm{Na}_{2} \mathrm{O}-\mathrm{P}_{2} \mathrm{O}_{5}-$ $\mathrm{H}_{2} \mathrm{O}$, then a dissolution reaction involving the $\mathrm{NaZnPO}_{4}$ solid is required. Recall also that various $Z n$ (II) phosphatocomplex forms are possible in aqueous phosphate solutions. The following phosphato complexes of the unhydrolyzed zinc(II) ion have been reported: $\mathrm{Zn}\left(\mathrm{HPO}_{4}\right)(\mathrm{aq})^{\left({ }^{8}\right)}$ and $\mathrm{Zn}\left(\mathrm{H}_{2} \mathrm{PO}_{4}\right)^{+\left({ }^{9}\right)}$; similar complexes involving hydrolyzed, divalent zinc ions are possible, although information concerning these equilibria is not yet available. By similarity to the reported solubility behavior of copper(II) oxide in aqueous sodium phosphate ${ }^{(10)}$, we may expect significant concentrations of $\mathrm{Zn}(\mathrm{OH})_{2}\left(\mathrm{HPO}_{4}\right)=$ to be present. Therefore, the suggested dissolution reactions are:

$$
\mathrm{ZnO}(\mathrm{s})+\mathrm{H}_{2} \mathrm{O}+\mathrm{HPO}_{4}^{=} \neq \mathrm{Zn}(\mathrm{OH})_{2}\left(\mathrm{HPO}_{4}\right)=
$$


and $\mathrm{NaZnPO}_{4}(\mathrm{~s})+2 \mathrm{H}_{2} \mathrm{O}+\mathrm{HPO}_{4}^{=} \neq \mathrm{Na}^{+}+\mathrm{Zn}(\mathrm{OH})_{2}\left(\mathrm{HPO}_{4}\right)=+\mathrm{H}_{2} \mathrm{PO}_{4}^{-}$

The concentrations of each possible zinc(II) ion complex were then calculated in terms of an equilibrium constant for either a stepwise hydrolys is reaction, i.e.:

$$
\begin{gathered}
\mathrm{Zn}(\mathrm{OH})_{2}(\mathrm{aq})+\mathrm{H}_{2} \mathrm{O} \neq \mathrm{Zn}(\mathrm{OH})_{3}^{-}+\mathrm{H}^{+} \\
\mathrm{Zn}(\mathrm{OH})_{3}^{-}+\mathrm{H}_{2} \mathrm{O} \neq \mathrm{Zn}(\mathrm{OH})_{4}^{=}+\mathrm{H}^{+}
\end{gathered}
$$

or a phosphatocomplexing reaction, i.e.:

$$
\begin{gathered}
\mathrm{Zn}(\mathrm{OH})_{2}(\mathrm{aq})+\mathrm{HPO}_{4}^{-} \ddagger \mathrm{Zn}(\mathrm{OH})_{2}\left(\mathrm{HPO}_{4}\right)= \\
\mathrm{Zn}(\mathrm{OH})_{3}^{-}+\mathrm{H}_{2} \mathrm{PO}_{4}^{-} \ddagger \mathrm{Zn}(\mathrm{OH})_{3}\left(\mathrm{H}_{2} \mathrm{PO}_{4}\right)=\text {, etc. }
\end{gathered}
$$

The thermodynamic relationships

$$
-R T \text { en } K=\Delta G=\Delta H-T \Delta S
$$

were introduced at this point to allow calculation of all zinc(II) ion complex concentrations as functions of temperature. The total molality of zinc in solution was then calculable by summation over the mononuclear zinc(II) species present. Where possible, a three parameter model was used to describe $\Delta G$ as a function of temperature. This approximation assumes that the difference in heat capacities between reactants and products for each reaction is a constant (C). Integration of the applicable thermodynamic relationships gives 


$$
\Delta H=A+C T \text { and } \Delta S=B+C e n T \text {, }
$$

where $A, B$, and $C$ are fitted constants.

To evaluate the experimental soiubilities of Table III in terms $c r$ concentrations of the possible complexed/hydrolyzed zinc species present required that the $\mathrm{pH}$ (hydronium ion concentration) be known at the existing solution conditions. This quantity depended on the sodium phosphate molality, as well as the orthophosphate ion and water dissociation constants. These parameters, which are functions of solution temperature, are defined below and tabulated in Table IV.

$$
\begin{aligned}
K_{W} & =\left[H^{+}\right]\left[\mathrm{OH}^{-}\right] \\
Q_{1} & =\frac{\left[\mathrm{H}_{2} \mathrm{PO}_{4}^{-}\right]}{\left[\mathrm{H}_{3} \mathrm{PO}_{4}\right]\left[\mathrm{OH}^{-}\right]} \\
Q_{2} & =\frac{\left[\mathrm{HPO}_{4}^{=}\right]}{\left[\mathrm{H}_{2} \mathrm{PO}_{4}^{-}\right]\left[\mathrm{OH}^{-}\right]} \\
Q_{3} & =\frac{\left[\mathrm{PO}_{4}\right]}{\left[\mathrm{HPO}_{4}^{-}\right]\left[\mathrm{OH}^{-}\right]} \\
\text {with } \log \mathrm{K} & =\frac{A}{T}+\mathrm{B}+\mathrm{C} \text { en } T+\frac{E}{T^{2}}
\end{aligned}
$$

Deviations from ideal solution behavior were accounted for by distinguishing between ionic concentration and thermodynamic activity: 


$$
a_{i}=r_{i} C_{i}
$$

where $a_{j}$ is the thermodynamic activity, $\gamma_{j}$ the ionic activity and $C_{j}$ is the ionic concentration. Generaliy, it was assumed that ionic activity coefficients could be related to ionic strength by an extended Debye-Huckel expression ${ }^{(14)}$ :

$$
\log \gamma_{i}=\frac{-S Z_{i}^{2} / I}{1+1.5 \checkmark I}
$$

where $S$ is the limiting Debye-Huckel slope $(\equiv 0.51 \text { at } 298 \mathrm{~K})^{\left({ }^{11}\right)}, Z_{i}$ is the ionic charge number, and $I$ is the ionic strength $=\sum \xi_{2} C_{i} Z_{i}{ }^{2}$. Dissociation constants $K_{W}, Q_{1}$, and $Q_{2}$ were corrected for ionic strength via literature correlations $\left(11\right.$ and $\left.{ }^{12}\right)$. $K_{W}$ was corrected to a pressure of $8.97 \mathrm{MPa}$ using the correlation presented in Reference 11.

TABLE IV. Dissociation Behavior of Selected Compounds

Compound Undergoing

Dissociation
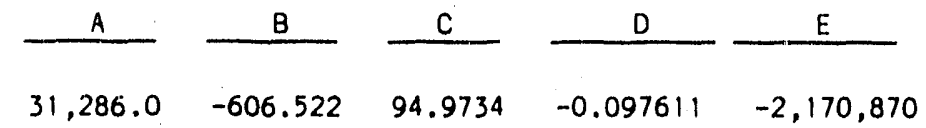

Reference Cited

$\mathrm{H}_{2} \mathrm{O}$

$31,286.0$

$-606.522$

94.9734

$$
0.097611-2,170,870
$$

Sweeton, Mesmer

$\mathrm{H}_{3} \mathrm{PO}_{4}$

$17,655.8 \quad-253.198$

39.4277

$-0.0325405$

$-810,134$

and Baes (11)

$\mathrm{H}_{2} \mathrm{PO}_{4}^{-}$

$17,156.9-246.045$

$37.7345-0.0322082$

$-897,579$

Mesmer and Baes (12)

$\mathrm{HPO}_{4}=$

$-106.51$

7.1340

$-0.017459$

Mesmer and Baes (12)

An overall neutrality balance was finally used to determine $\left[H^{+}\right]$for each data point. For the most general case, the balance is: 


$$
\begin{gathered}
\sum_{n=3}^{4}(2-n)\left[\mathrm{Zn}(\mathrm{OH})_{n}{ }^{(2-n)+}\right]+\sum_{k=1}^{3} \sum_{m=2}^{4}(2-m-k)\left[\mathrm{Zn}(\mathrm{OH})_{m}\left(\mathrm{H}_{2} \mathrm{PO}_{4}\right)_{k}{ }^{(2-m-k)+}\right] \\
+\sum_{i=1}^{3} \sum_{p=2}^{4}(2-p-2 i)\left[\mathrm{Zn}(\mathrm{OH})_{p}\left(\mathrm{HPO}_{4}\right)_{i}^{(2-p-2 i)+}\right]+\left[\mathrm{Na}^{+}\right]+\left[\mathrm{H}^{+}\right]= \\
{\left[\mathrm{OH}^{-}\right]+3\left[\mathrm{PO}_{4}\right]+2\left[\mathrm{HPO}_{4}^{=}\right]+\left[\mathrm{H}_{2} \mathrm{PO}_{4}^{-}\right]}
\end{gathered}
$$

Since the $\mathrm{Zn}(\mathrm{OH})_{2}\left(\mathrm{HPO}_{4}\right)=$ ion concentration was given in terms of the equilibrium constant for Equation (3) or (4), and the concentrations of the hydrolyzed and complexed $Z n$ (II) species were calculable in terms of equilibrium constants for Equations (5) to (6), the neutrality balance was reduced to an algebraic equation in terms of the unknown, $\left[H^{+}\right]$. To determine how a given scheme of $\mathrm{Zn}$ (II) complexes in solution could fit the results, a set of thermodynamic constants was substituted into the neutrality balance (Equation 14), and $\left[\mathrm{H}^{+}\right]$concentrations were calculated by a Newton-Raphson iteration procedure. These $\left[\mathrm{H}^{+}\right]$values were then used to compute all the soluble zinc species which, after being summed, could be compared with the measured $\mathrm{Zn}$ solubilities. The differences were then minimized via a generalized, nonlinear, least-squares curve-fitting routine based on Marquardt's a) gorithm $(15)$.

When the solubility data were analyzed, the importance of relative errors (i.e., percentage errors), rather than absolute errors, was accounted for by minimizing differences between the logarithms of the experimental and the predicted solubilities. The thermodynamic functions obtained in this manner were then resubstituted into the neutrality balance, and the two-step process 
was repeated. Convergence, i.e., the condition when the calculated thermodynamic functions ceased to change, was attained in a few cycles because the dissolved metal ion concentrations were low and had only a minor influence on chariges in solution $\mathrm{pH}$.

Results of the data-fitting procedure are illustrated graphically in Figures 2 through 4 . The predominant species were found to be $\mathrm{Zn}(\mathrm{OH})_{2}\left(\mathrm{HPO}_{4}\right)=$, $\mathrm{Zn}(\mathrm{OH})_{3}^{-}$and $\mathrm{Zn}(\mathrm{OH})_{2}(\mathrm{aq})$; three parameter fits yielded statistically significant correlations. The presence of two other anionic $\mathrm{Zn}$ (II) complexes $\left[\mathrm{Zn}(\mathrm{OH})_{4}\right.$ and $\mathrm{Zn}(\mathrm{OH})_{3}\left(\mathrm{H}_{2} \mathrm{PO}_{4}\right)=1$ were also fitted in a statistically significant manner. Due to their lower concentrations, a two parameter thermodynamic model proved to be sufficient; i.e., $\Delta H$. and $\Delta S$ were taken to be indcpendent of temperature.

Table $V$ presents the thermodynamic quantities fitted to the $\mathrm{ZnO}$ and $\mathrm{NaZnPO}_{4}$ dissolution reactions and the subsequent $\mathrm{Zn}$ (II) ion hydrolysis and complexing reactions. This fit resulted in an overall standard deviation between measured and fitted $\mathrm{Zn}$ solubilities of $9 \%$.

\section{DISCUSSION}

Zinc Oxide Dissolution into $\mathrm{Zn}(\mathrm{OH})_{2}(\mathrm{aq})$

Because solution $\mathrm{pH}$, hence the hydrolytic state of the zinc(II) ion, was controlled by the quantity of sodium phosphate added, it was not possible to complex measureable levels of $\mathrm{Zn}^{+2}$ and $\mathrm{Zn}(\mathrm{OH})^{+}$in the present experimental program. 


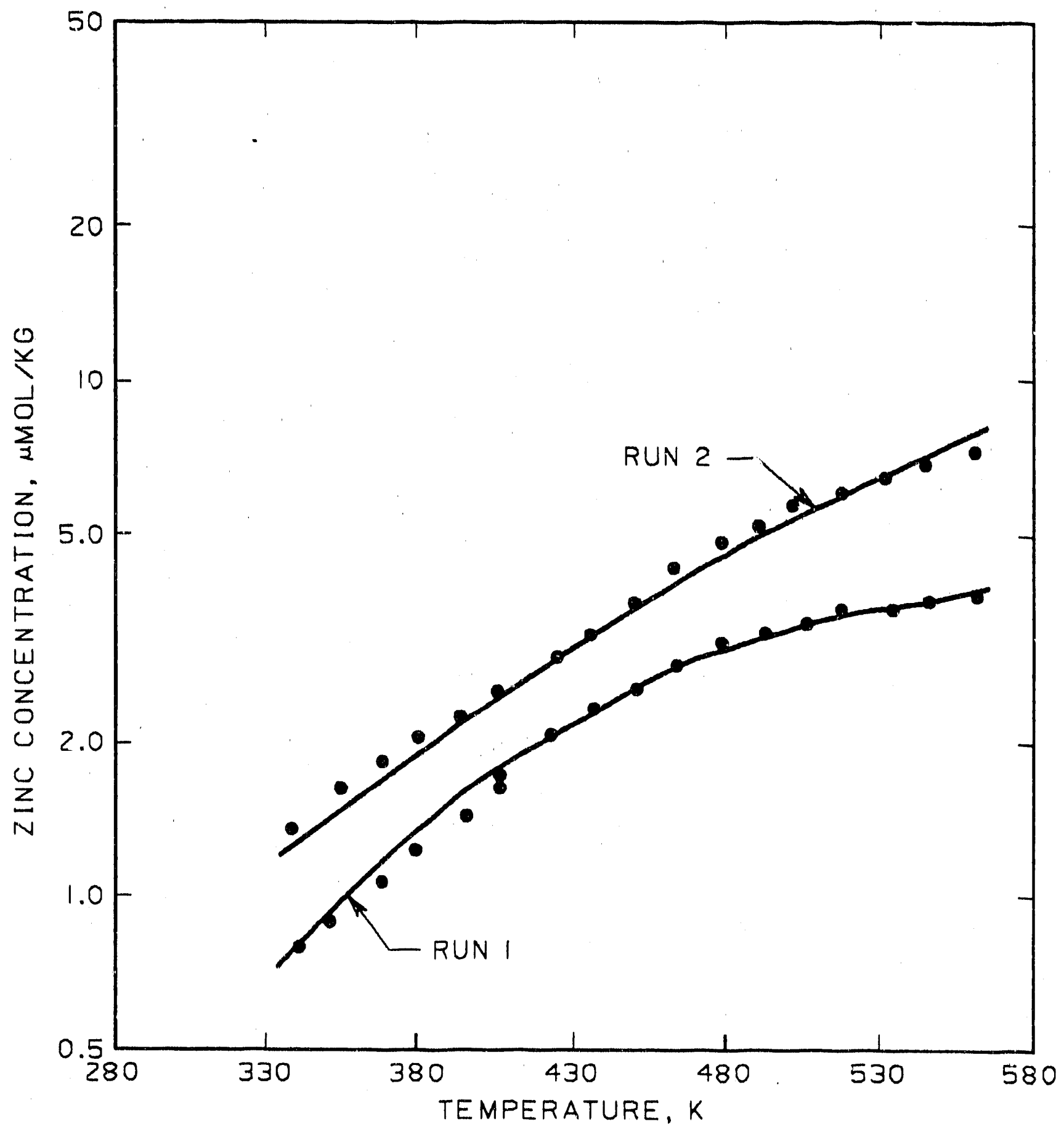

Figure 2. Comparison of Measured and Fitted Solubilities of Zinc Oxide in Sodium Phosphate Solutions $(\mathrm{Na} / \mathrm{P}=2.3)$. 


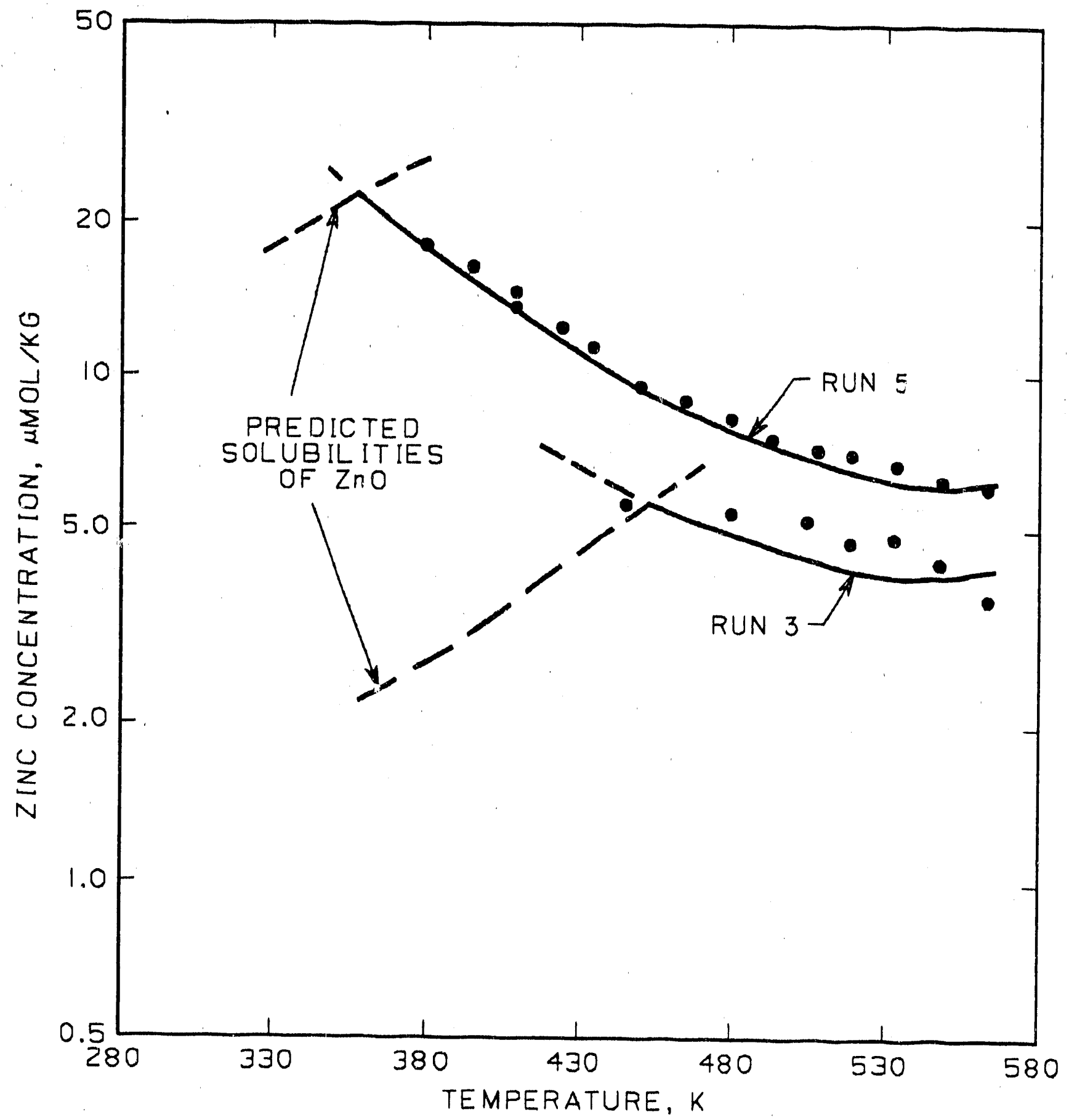

Figure 3. Comparison of Measured and Fitted Solubilities of $\mathrm{NaZnPO}_{4}$ in Sodium Phosphate Solutions $(\mathrm{Na} / \mathrm{P}=2.3)$. 


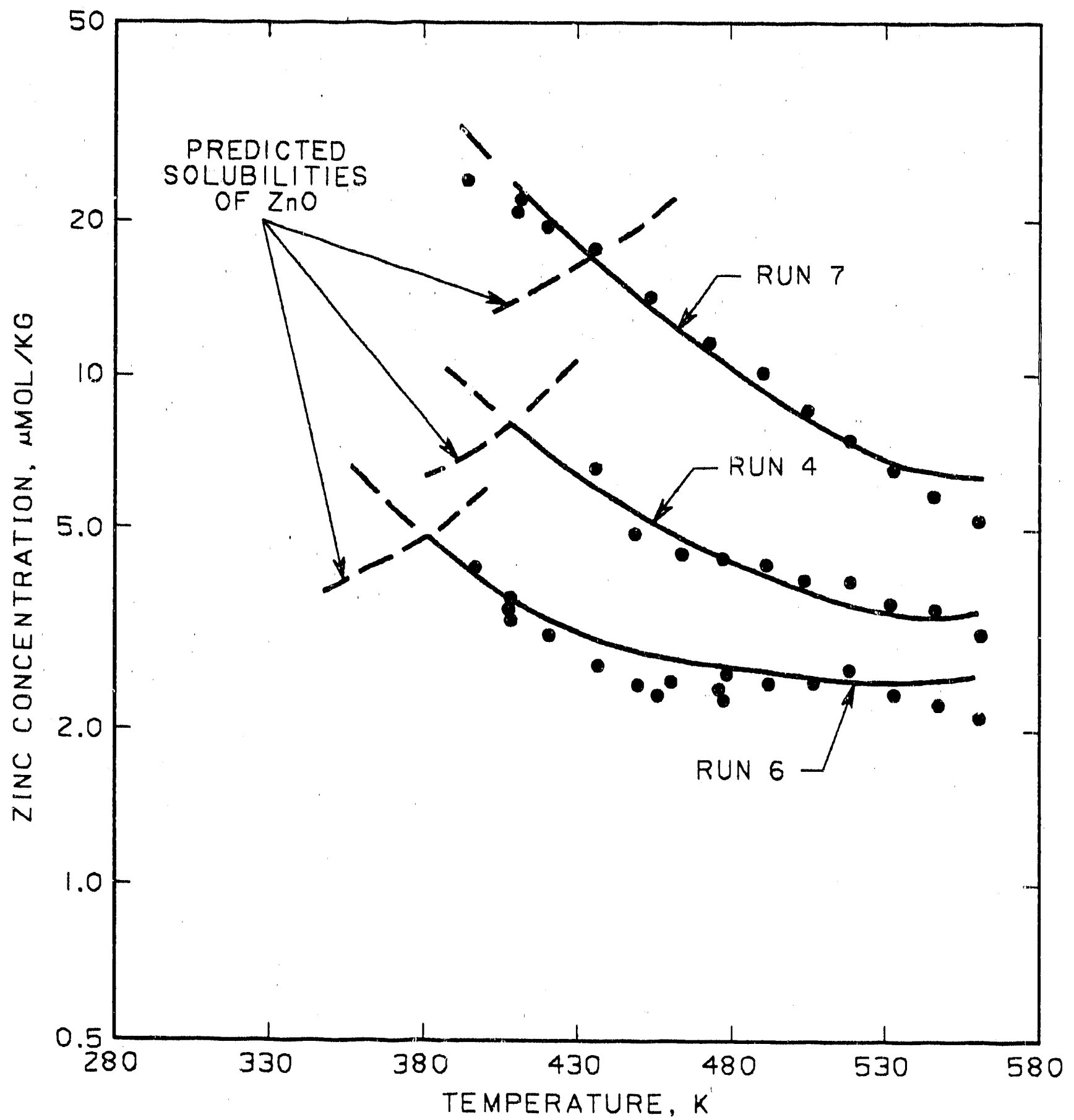

Figure 4. Comparison of Measured and Fitted Solubilities of $\mathrm{NaZnPO}_{4}$ in Sodium Phosphate Solutions $(P=10.5 \mathrm{mmol} / \mathrm{kg})$. 


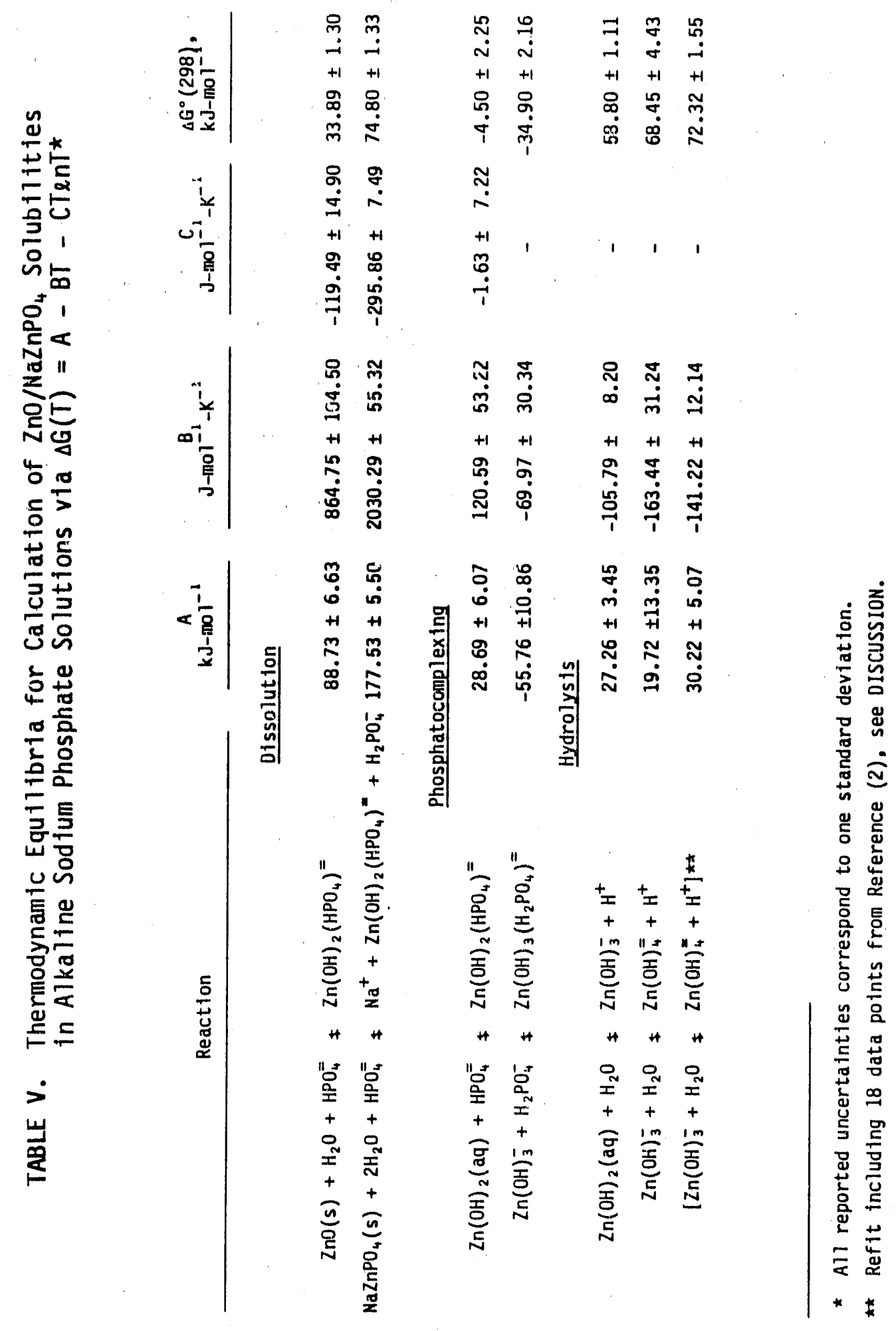


The standard free energy change for zinc oxide dissolution into the lowest zinc(II) hydrolytic state, $\mathrm{Zn}(\mathrm{OH})_{2}(\mathrm{aq})$, was determined from Table $V$ to be $38.16 \pm 3.56 \mathrm{~kJ} / \mathrm{mol}$. This result indicates a $\mathrm{Zn}(\mathrm{OH})_{2}(\mathrm{aq})$ solubility of 0.2 $\mu \underline{m}$ at room temperature. A "literature" value for comparison purposes may be obtained by combining standard free energy changes reported for

$$
\mathrm{ZnO}(\mathrm{s})+2 \mathrm{H}^{+} \neq \mathrm{Zn}^{+2}+\mathrm{H}_{2} \mathrm{O}
$$

and

$$
\mathrm{Zn}^{+2}+2 \mathrm{H}_{2} \mathrm{O} \neq \mathrm{Zn}(\mathrm{OH})_{2}(\mathrm{aq})+2 \mathrm{H}^{+}
$$

Schindler et a ${ }^{\left({ }^{16}\right)}$ have measured $-63.58 \pm 0.18 \mathrm{~kJ}$ for Equation (15), while Baes and Mesmer ${ }^{(1)}$ recommend $96.44 \pm$ ?kJ for Equation (16), but state that a higher value would be expected. These values combine to give the Equation (2) equilibrium for $n=2$ as $\Delta G^{\circ}(298)=32.86 \mathrm{~kJ}$. This estimate indicates a $\mathrm{Zn}(\mathrm{OH})_{2}(\mathrm{aq})$ solubility of $1.75 \mu \mathrm{m}$, which is clearly too high compared with our Zrio solubility measurements (see Figure 2 ).

Free energy changes for zinc oxide dissolution at elevated temperatures, as determined from a combination of equilibria summarized in Table $V$, are plotted in Figure 5 . The results of Khodakovskii and Elkin $\left.{ }^{2}\right)$, obtained at temperatures between 373 and $473 \mathrm{~K}$, are seen to be higher by a maximum of $5 \mathrm{~kJ}$ at $473 \mathrm{~K}$. Given an estimated uncertainty of $\pm 2.9 \mathrm{~kJ}$ for our experimental results at $473 \mathrm{~K}$, the difference is not statistically significant. Note that the lowest Zno solubility value reported by Khodakovskii and Elkin at $373 \mathrm{~K}$ $(1.8 \mu \mathrm{m})$ is also consistent with our higher $\Delta G^{\circ}(298)$ estimate, because most of the soluble $\mathrm{Zn}(\mathrm{II})$ was present as $\mathrm{Zn}(\mathrm{OH})_{3}^{-}$rather than $\mathrm{Zn}(\mathrm{OH})_{2}(\mathrm{aq})$. 


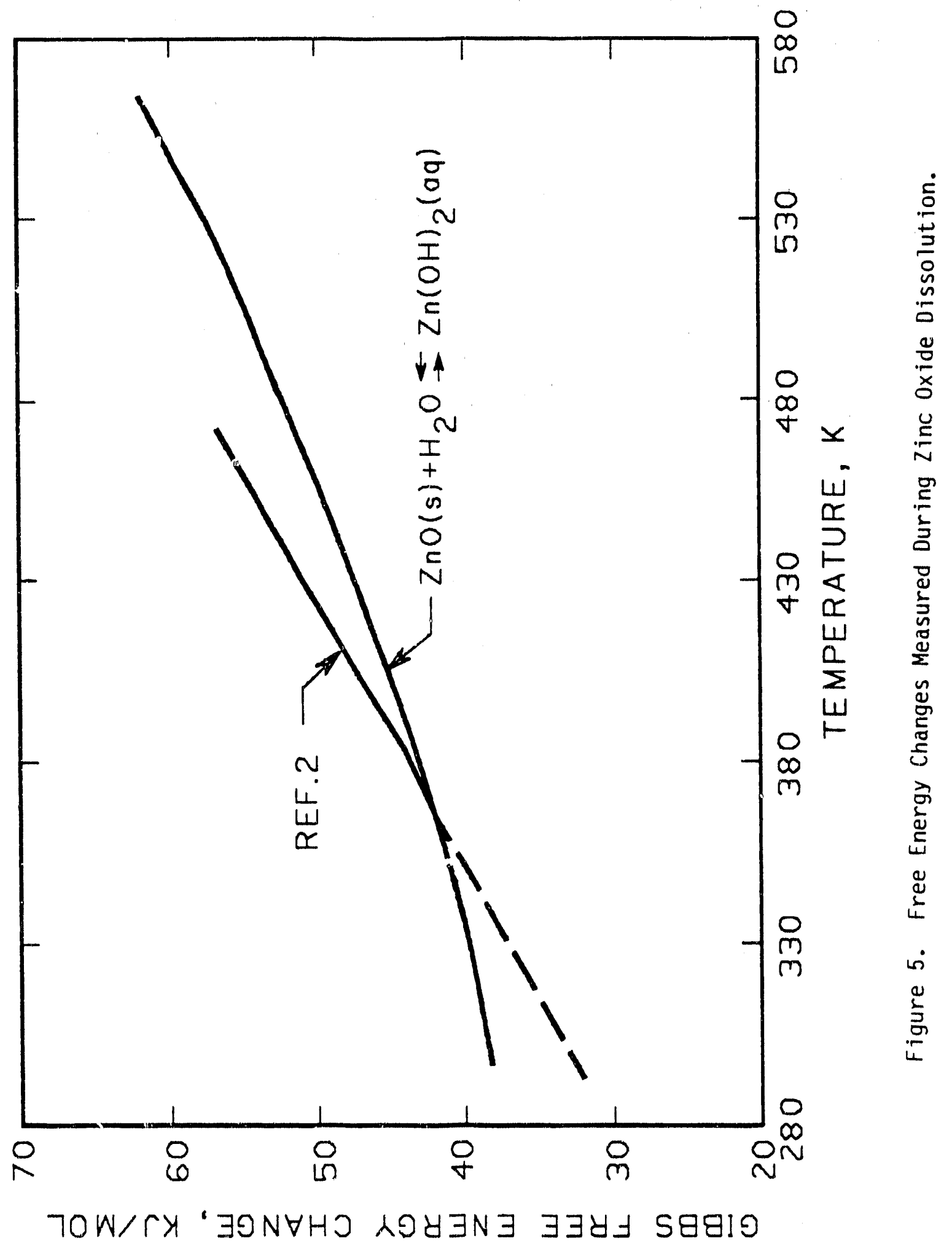


The above discussion is consistent with an equilibrium that exhibits a nonlinear $\Delta G(T)$ behavior. On the basis of the fitted $\Delta C_{p}^{\circ}(298)$ for the $Z n 0$ dissolution reaction $(-117.9 \mathrm{~J} / \mathrm{K})$ and tabulated standard heat capacities (see Table VI), the standard heat capacity for the $\mathrm{Zn}(\mathrm{OH})_{2}(\mathrm{aq})$ hydroxocomplex is calculated to be $-2.3 \mathrm{~J} / \mathrm{K}$.

\section{Zn(II) Ion Hydrolysis}

Standard free errergy changes for the third and fourth stepwise hydrolysis reactions of the $\mathrm{Zn}$ (II) ion were determined to be $58.83 \pm 1.11$ and $68.43 \pm$ $4.43 \mathrm{~kJ}$, respectively. A literature value for $\Delta G^{\circ}(298)$ of the third stepwise hydrolysis reaction, derived via difference between $\Delta G^{\circ}$ for the triple hydrolysis reaction recommended by Baes and $\operatorname{Mesmer}\left({ }^{1}\right)$ and our revised $\Delta G^{\circ}$ estimate for Equation (16), is $60.34 \mathrm{~kJ}$. Similarly, literature values recommended by Baes and Mesmer (') ${ }^{1}$ give $\Delta G^{\circ}(298)=73.05 \pm 1.14 \mathrm{~kJ}$ for the fourth stepwise hydrolysis reaction. In neither case is the disagreement considered to be statistically significant.

The high-temperature equilibria for the above hydrolysis reactions are shown in Figure 6 . These results are compared with the results of khodakorskii and Elkin ${ }^{(2)}$, who determined these hydrolysis equilibria in terms of reaction with the hydroxyl ion:

$$
\begin{gathered}
\mathrm{Zn}(\mathrm{OH})_{2}(\mathrm{aq})+\mathrm{OH}^{-} \mp \mathrm{Zn}(\mathrm{OH})_{3}^{-} \\
\Delta G(\mathrm{~T})=1.5314-99.41 \mathrm{~T}
\end{gathered}
$$

and

$$
\begin{aligned}
\mathrm{Zn}(\mathrm{OH})_{3}^{-}+\mathrm{OH}^{-} \mp \mathrm{Zn}(\mathrm{OH})_{4}^{=} \\
\Delta \mathrm{G}(\mathrm{T})=-17324+35.32 \mathrm{~T}
\end{aligned}
$$




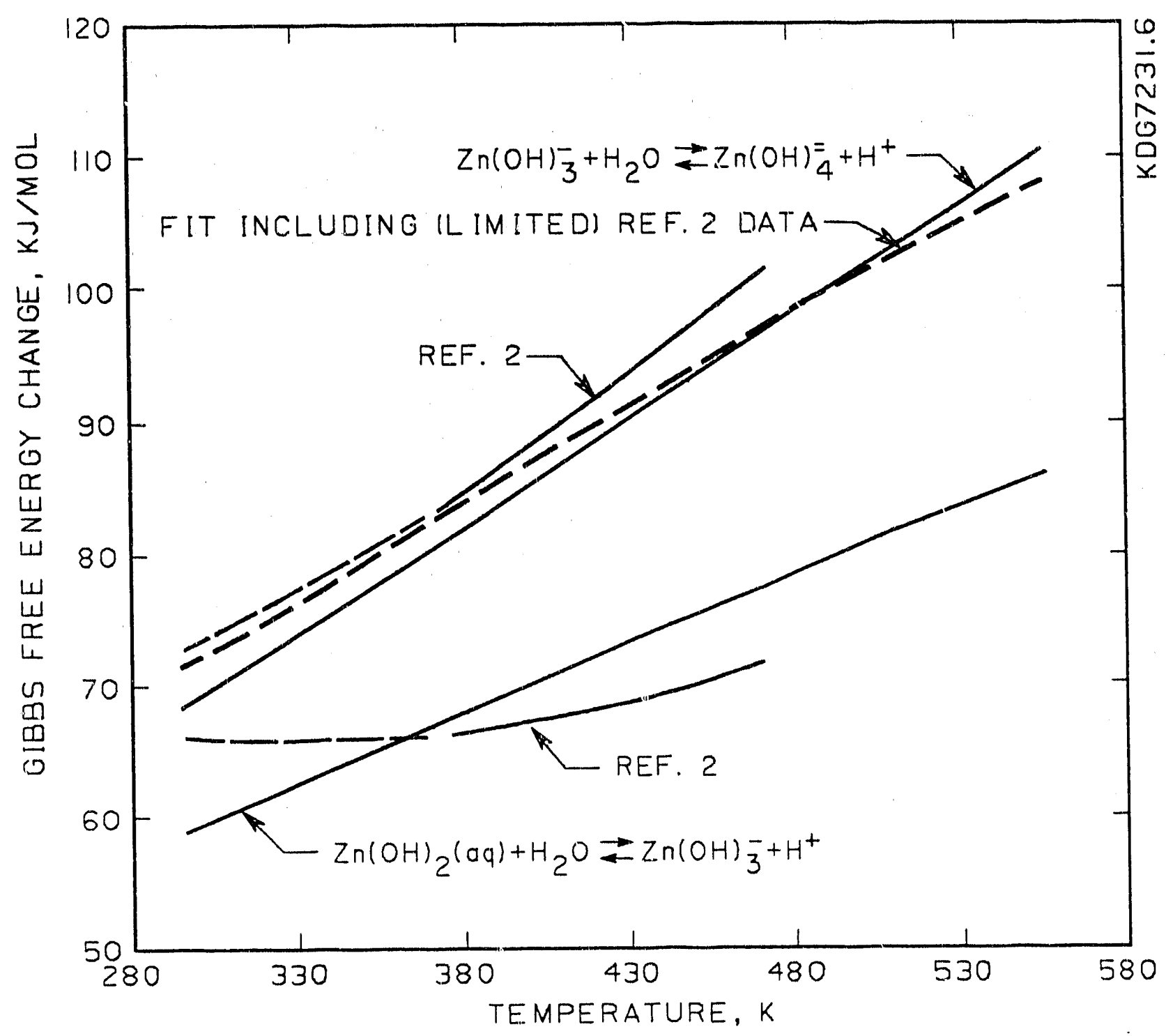

Figure 6. Comparison of Free Energy Changes Associated with $\mathrm{Zn}$ (II) Ion Hydrolysis Reactions. 
These free energy changes were converted to the form of Equations (5) by adding $\Delta G_{w}$. Results of the two investigations are seen to differ by up to 6 $k J$ over the temperature range $298-473 \mathrm{~K}$.

The source of this discrepancy, with regard to calculation of the third stepwise hydrolysis reaction equilibrium, lies in the analytical methodology selected by Khodakovskif and Elkin $\left.{ }^{2}\right)$ : an assumed linear $\Delta G(T)$ dependency fitted to the Equation (17) equilibrium necessarily implies that the corresponding Equation (5) equilibrium will exhibit the nonlinear $\Delta G(T)$ characteristics shown in Figure 6. This phenomenon is not believed to be real, because subsequent introduction of a heat capacity term into the Equation (5) equilibrium did not yield a meaningful fit.

On the other hand, the 1 imited $\mathrm{pH}$ range covered by the present investigation was responsible for relatively imprecise estimates of the fourth stepwise hydrolysis reaction equilibrium. Because higher alkalinities were tested by Khodakovskif and Elkin (the pH range 11 through 13 was represented by 18 data points), their estimate of this equilibrium was more precise than ours. Therefore, the above data points were included in our database and a new least-squares fit was performed*. The new fit is compared with the added data in Figure 7. With the exception of the fourth hydrolysis reaction equilibrium, the modified fit yielded results virtually identical to the original fit. Upgraded thermodynamic parameters for the fourth hydrolys is equilibrium are given in Table $V$. As shown in Table $V$ and Figure 6 , the modified fit

* System pressures at the three temperatures tested were assumed to bi $10 \%$ above saturation. 


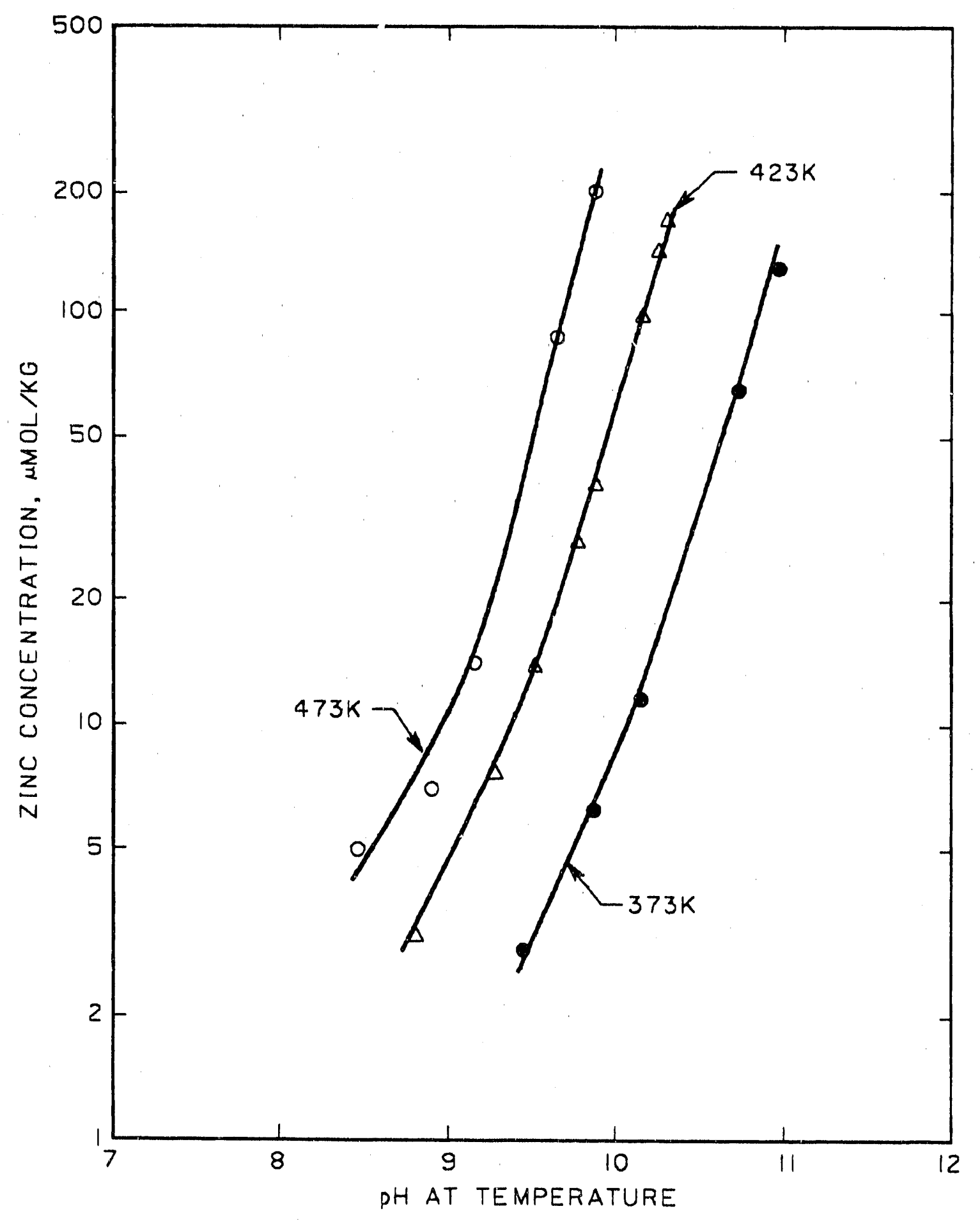

Figure 7. Comparison of Measured and Fitted Solubilities of Zinc Oxide in Sodium Hydroxide Solutions. Data Taken from Khodakovskij and Elkin. (2) 
increases the precision of the fourth hydrolysis equilibrium and brings about a much closer agreement between the two studies.

By way of closure, Table VI provides a summary of thermochemical properties of species in the $\mathrm{ZnO}-\mathrm{H}_{2} \mathrm{O}$ system. Inconsistencies in the literature have led to different recommended properties for $\mathrm{Zn}(\mathrm{OH})^{+}$by two independent reviews $\left({ }^{1}, 2\right)$. We conclude that the subsequent inclusion of three Zno solubility measurements in pure water by Khodakovskif and Elkin $\left.{ }^{2}\right)$ is insufficient to reliably determine two $\mathrm{Zn}(\mathrm{OH})^{+}$properties $\left(\Delta \mathrm{H}_{f}^{\circ}, \mathrm{S}^{\circ}\right)$. However, by assuming that $\mathrm{Zn}$ (II) hydrolysis is similar to that for $\mathrm{Cu}$ (II), we expect $\mathrm{Zn}(\mathrm{OH})^{+}$to exhibit $\Delta \mathrm{G}^{\circ}(298) \approx 55 \mathrm{~kJ}^{-\mathrm{mol}^{-1}}$ for stepwise hydrolys is (similar to $\left.\left({ }^{1}\right)\right)$ and to possess a large, positive ionic entropy (similar to ${ }^{(2)}$ ).

All ionic entropies for the families of $\mathrm{Zn}$ (II) and CU(II) hydroxocomplexes, therefore, are positive quantities (see figure 8 ). Since unhydrolyzed metal ion entropies are negative, hydroxocomplex formation is viewed as a structure-breaking process. This behavior may indicate a change in coordination number of the central metal ion from six to four.

\section{$\underline{\mathrm{ZnO} / \mathrm{NaZnPO}} 4$ Transformation}

The thermodynamic instability of zinc oxide in concentrated sodium phosphate solutions is explained by the precipitation of a sodium salt of the phosphato-hydroxo-zincate ion. By combining fitted chemical equilibria for the $\mathrm{ZnO}$ and $\mathrm{NaZnPO}_{4}$ dissolution reactions, an equilibrium constant may be derived for the overall transformation reaction:

$$
\mathrm{ZnO}(\mathrm{s})+\mathrm{Na}^{+}+\mathrm{H}_{2} \mathrm{PO}_{4}^{-} \neq \mathrm{NaZnPO}_{4}(\mathrm{~s})+\mathrm{H}_{2} \mathrm{O}
$$


TABLE VI. Thermochemical Parameters for Species in the $\mathrm{ZnO}-\mathrm{H}_{2} \mathrm{O}$ system

\begin{tabular}{|c|c|c|c|c|c|}
\hline Species & $\begin{array}{l}C_{p}^{0}(298) \\
\underline{J-m o l^{-1}}-k^{-1}\end{array}$ & $\begin{array}{l}S^{\circ}(298) \\
{\underline{J}-m o l^{-1}}^{-K^{-1}}\end{array}$ & $\begin{array}{l}\Delta H_{f}^{\circ}(298) \\
\mathrm{kJ}^{-m o l^{-1}}\end{array}$ & $\begin{array}{c}\Delta G_{f}^{\circ}(298) \\
k J-m o l^{-1}\end{array}$ & $\begin{array}{c}\text { Reference } \\
\text { Cited } \\
\end{array}$ \\
\hline $\ln (s)$ & 25.40 & $41.63 \pm 0.21$ & 0 & 0 & 17 \\
\hline$\varepsilon-\mathrm{Zn}(\mathrm{OH})_{2}(\mathrm{~s})$ & 72.4 & $76.99 \pm 0.21$ & -645.47 & $-555.93 \pm 0.21$ & 2 \\
\hline $\mathrm{ZnO}(\mathrm{s})$ & 40.25 & $43.64 \pm 0.42$ & $-350.83 \pm 0.21$ & $-320.91 \pm 0.25$ & 17 \\
\hline $\mathrm{H}_{2}(\mathrm{~g})$ & 28.83 & $130.58 \pm 0.08$ & 0 & 0 & 17 \\
\hline $\mathrm{O}_{2}(\mathrm{~g})$ & 29.37 & $205.02 \pm 0.04$ & 0 & 0 & 17 \\
\hline$H^{+}(a q)$ & -71 & -22.2 & 0 & 0 & 18,19 \\
\hline $\mathrm{H}_{2} \mathrm{O}$ & 75.31 & $69.96 \pm 0.08$ & $-285.85 \pm 0.04$ & $-237.19 \pm 0.04$ & 17 \\
\hline $2 n^{+2}(a q)$ & -164 & $-154.8 \pm 1.3$ & $-153.64 \pm 0.42$ & -147.23 & 2,19 \\
\hline $\mathrm{Zn}(\mathrm{OH})^{+}(\mathrm{aq})$ & - & * & * & $\begin{array}{l}-333.3 \\
-342.0\end{array}$ & $\begin{array}{l}1 \\
2\end{array}$ \\
\hline $\mathrm{Zn}(\mathrm{OH})_{2}(\mathrm{aq})$ & -2.3 & 68.5 & -611.74 & -519.67 & This Work \\
\hline $\mathrm{Zn}(\mathrm{OH})_{3}^{-}(\mathrm{aq})$ & - & 54.9 & -870.31 & -698.08 & This Work \\
\hline $\mathrm{Zn}(\mathrm{OH})_{4}^{=}(\mathrm{aq})$ & - & 5.8 & -1125.96 & -862.97 & This Work \\
\hline
\end{tabular}

* No values are recommended due to widely conflicting results, i.e., $\mathrm{S}^{\circ}\left(\mathrm{ZnOH}^{+}\right)=$ $-46.2^{(1)}$ and $+42.7^{(2)} \mathrm{J}-\mathrm{mol}^{-1}-\mathrm{K}^{-1}$, see DISCUSSION. 


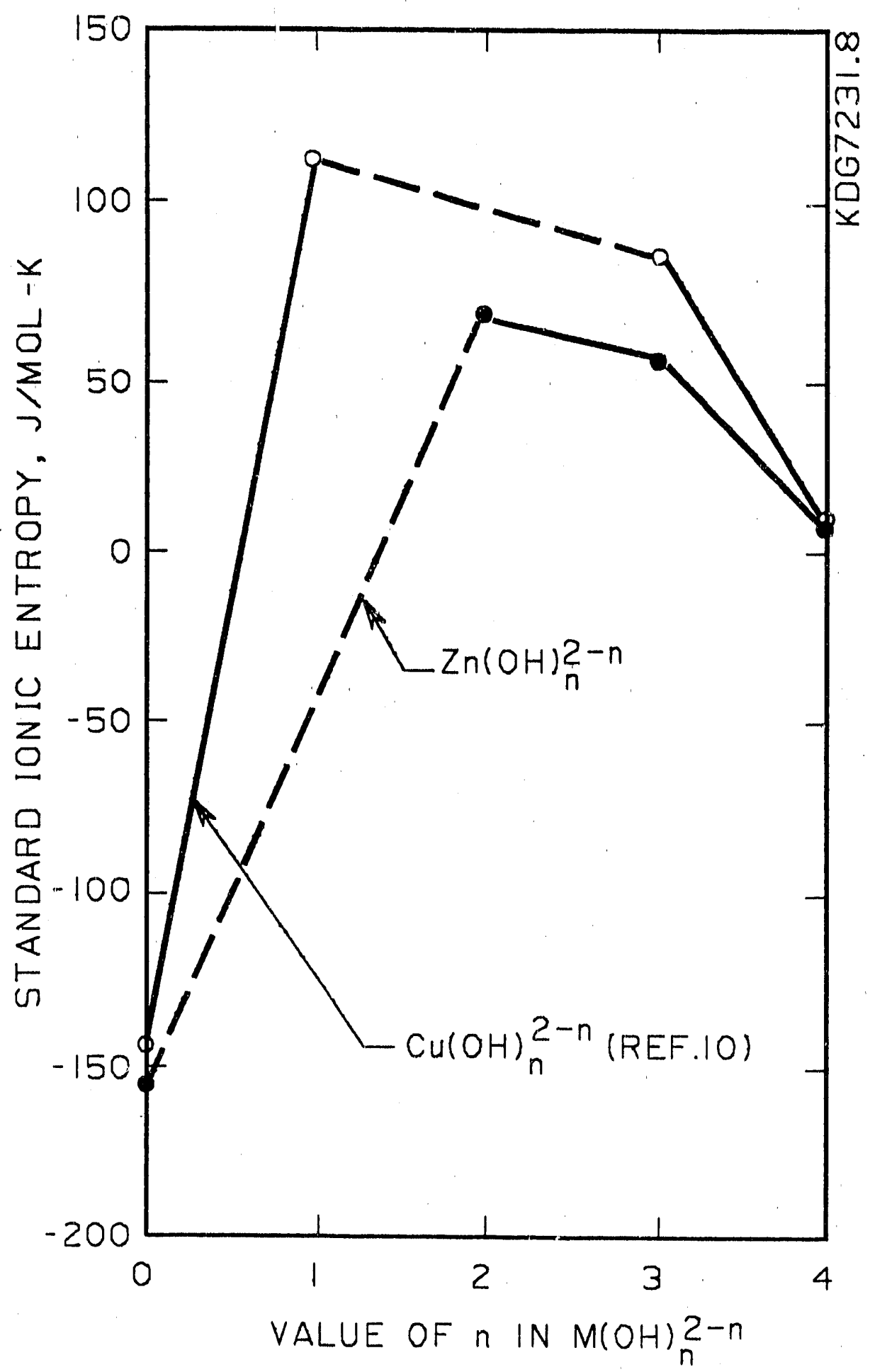

Figure 8. Standard Entropies for $\mathrm{Zn}$ (II) and $\mathrm{CU}$ (II) Ions and their Hydroxocomplexes. 
where $\quad \log k_{0}=-\log \left[\mathrm{Na}^{+}\right]\left[\mathrm{H}_{2} \mathrm{PO}_{4}^{-}\right]+\frac{2 \mathrm{~S} / \mathrm{I}}{1+1.5 \sqrt{ } \mathrm{I}}$

On the basis of Table $V$ values, it is found that

$$
\log k_{0}=\frac{4638.9}{T}-60.886+9.213 \ln T \text {. }
$$

Zinc oxide will remain stable as long as the sodium phosphate concentration product, $\left[\mathrm{Na}^{+}\right]\left[\mathrm{H}_{2} \mathrm{PO}_{4}^{-}\right]$, corrected for nonideal behavior by Equation (13), is less than the $1 / k_{0}$ value at a given temperature. Conversely, if the phosphate content increases so that $\left[\mathrm{Na}^{+}\right]\left[\mathrm{HPO}_{4}^{-}\right]>1 / \mathrm{k}_{0}$, then $\mathrm{ZnO}$ becomes unstable and will transform to $\mathrm{NaZnPO}_{4}$. This equilibrium concept is illustrated in Figure 9.

Another way of viewing this transformation is that the zinc compound with the lowest solubility is the one that precipitates from solution. Zinc oxide is stable at lower temperatures because the solubility limits of $\mathrm{NaZnPO}_{4}$ are very high. However, at high temperatures $\mathrm{NaZnPO}_{4}$ becomes sparingly soluble while the ZnO solubility limits increase greatly. The transformation line (i.e., phase boundary) shown in Figure 9 represents the locus of points at which the zinc solubility limits of the two phases -- $\mathrm{ZnO}$ and $\mathrm{NaZnPO}_{4}--$ are equa 1.

\section{Zn(II) Ion Phosphatocomplex Formation}

The distribution of $z$ inc(II) ion hydrolytic and phosphatocomplex species present in solution at 298 and $560 \mathrm{~K}$ is plotted in Figure 10 as a function of sodium phosphate concentration. It is readily seen that $\mathrm{Zn}(\mathrm{OH})_{2}\left(\mathrm{HPO}_{4}\right)=$ was the most prevalent phosphatocomplex form present in solution at high temperatures. Table VII summarizes the thermochemical properties of the 


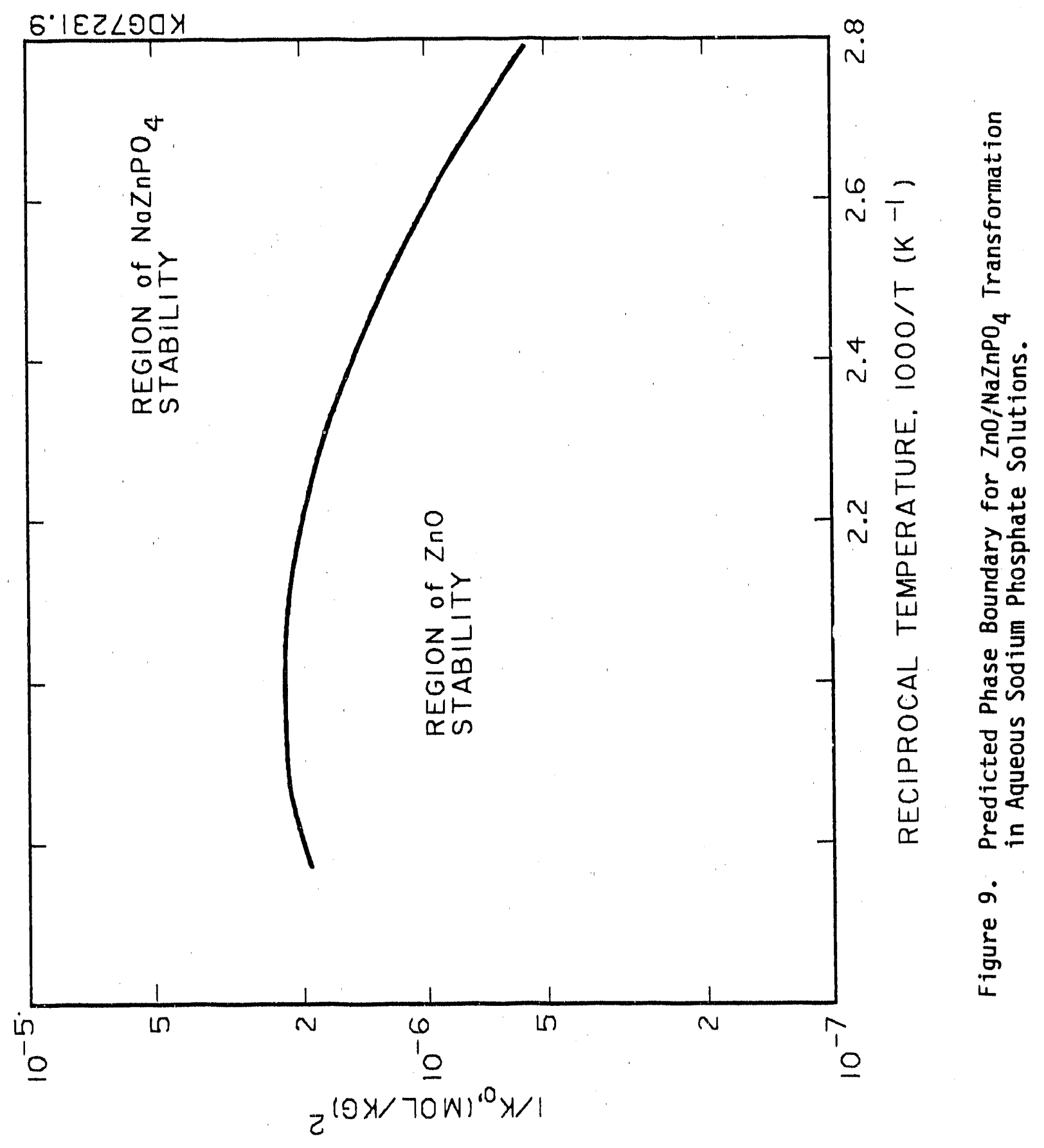




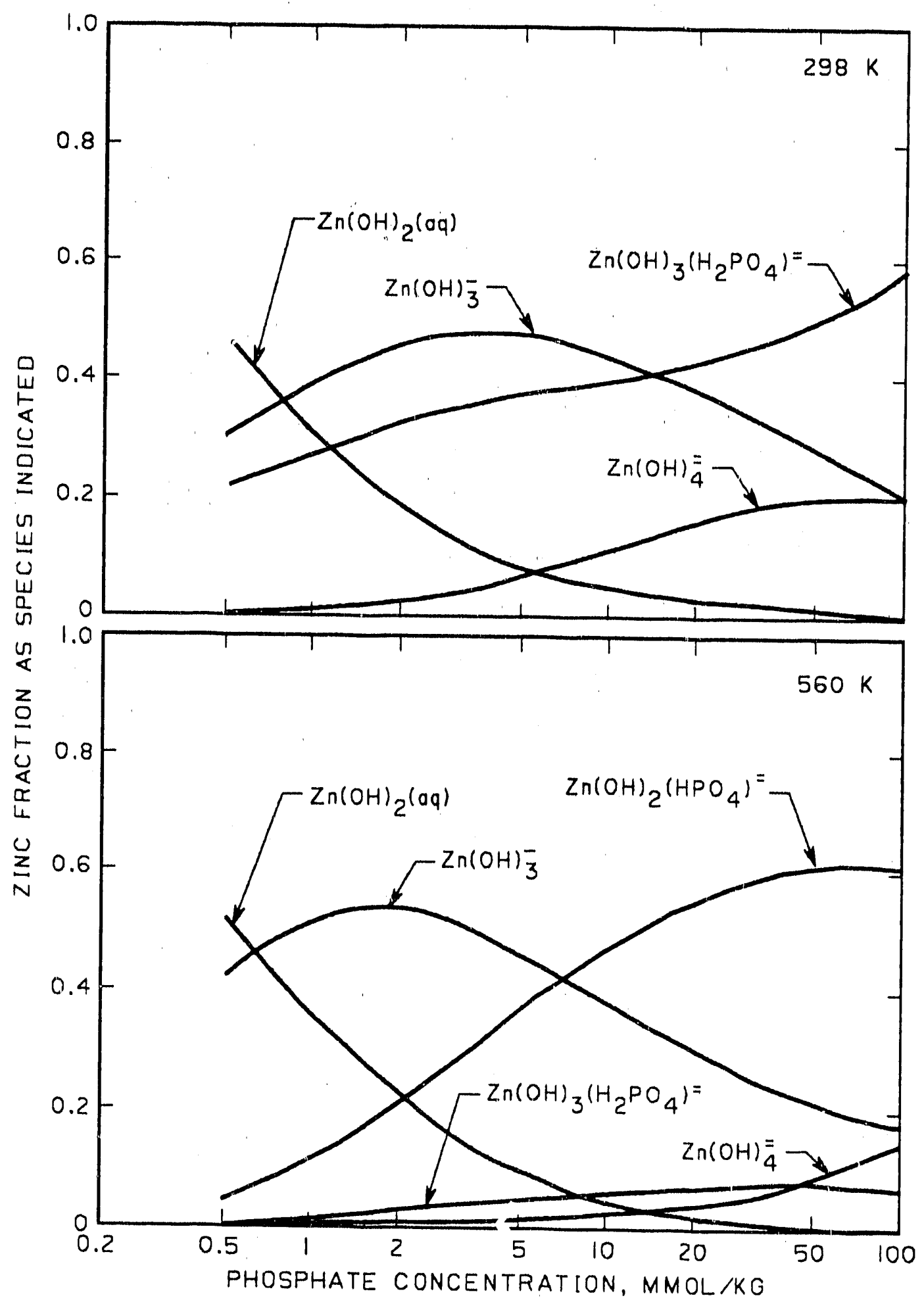

Figure 10. Distribution of $\mathrm{Zn}$ (II) Ion Complexes Present in Solution at $298 \mathrm{~K}$ (Top) and $560 \mathrm{~K}$ (Bottom). $(N / P=2.3)$. 
TABLE VII. Thermochemical Parameters for Phosphate-Based Species in the $\mathrm{ZnO}-\mathrm{Na}_{2} \mathrm{O}-\mathrm{P}_{2} \mathrm{O}_{5}-\mathrm{H}_{2} \mathrm{O}$ system

\begin{tabular}{|c|c|c|c|c|c|}
\hline Species & $\begin{array}{c}C_{p}^{0}(298)^{\star} \\
\underline{J-m o l^{-1}} \underline{-K}^{-1}\end{array}$ & $\begin{array}{l}S^{\circ}(298)^{\star} \\
\underline{J-m o 1}^{-1} \underline{-K}^{-1}\end{array}$ & $\begin{array}{l}\Delta H_{f}^{\circ}(298) \\
\mathrm{kJ}_{-\mathrm{mol}}{ }^{-1}\end{array}$ & $\begin{array}{l}\Delta G_{f}^{\circ}(298) \\
\underline{k J-m o l^{-1}}\end{array}$ & $\begin{array}{c}\text { Reference } \\
\text { Cited } \\
\end{array}$ \\
\hline $\mathrm{Na}(\mathrm{s})$ & 28.2 & 51.21 & 0 & 0 & 20 \\
\hline $\mathrm{Na}^{+}(\mathrm{aq})$ & -28 & 41.0 & -240.12 & -261.92 & 20 \\
\hline$P(s)$ & 23.8 & 41.1 & 0 & 0 & 20 \\
\hline$P O \overline{\bar{N}}(\mathrm{aq})$ & -283 & -153.6 & -1277.4 & -1018.8 & 20,21 \\
\hline $\mathrm{HPO}_{4}^{=}(\mathrm{aq})$ & -112 & -32.6 & -1305.5 & -1089.7 & 13,21 \\
\hline $\mathrm{H}_{2} \mathrm{PO}_{4}^{-}(\mathrm{aq})$ & 37 & 72.4 & -1308.8 & -1130.8 & 12,21 \\
\hline $\mathrm{NaZnPO}_{4}(\mathrm{~s})$ & 150.3 & 98.7 & -1650.0 & -1517.3 & This Work \\
\hline $\mathrm{Zn}\left(\mathrm{HPC}_{4}\right)^{\circ}(\mathrm{aq})$ & - & - & - & -1248.4 & 8 \\
\hline $\mathrm{Zn}\left(\mathrm{H}_{2} \mathrm{PO}_{4}\right)^{+}(\mathrm{aq})$ & - & - & - & -1285.2 & 9 \\
\hline $\mathrm{Zn}(\mathrm{OH})_{2}\left(\mathrm{HPO}_{4}\right)=(\mathrm{aq})$ & -115.9 & 145.5 & -1889.1 & -1613.9 & This Work \\
\hline $\mathrm{Zn}(\mathrm{OH})_{3}\left(\mathrm{H}_{2} \mathrm{PO}_{4}\right)=(\mathrm{aq})$ & - & 57.1 & -2234.8 & -1863.8 & This Work \\
\hline
\end{tabular}

* Ionic heat capacities and entropies are referred to an absolute scale where $C_{p}{ }^{\circ}\left(H^{+}\right)=-71 \mathrm{~J}-\mathrm{mol}^{-1}-\mathrm{K}^{-1}$ and $\mathrm{S}^{\circ}\left(H^{+}\right)=-22.2 \mathrm{~J}-\mathrm{mol}^{-1}-\mathrm{K}^{-1}$ (see Table VI). 
presently known species in the $\mathrm{ZnO}-\mathrm{Na}_{2} \mathrm{O}-\mathrm{P}_{2} \mathrm{O}_{5}-\mathrm{H}_{2} \mathrm{O}$ system based on the Table $\mathrm{V}$ equilibria and tabulated thermochemical properties of $\mathrm{H}_{2} \mathrm{PO}_{4}^{-}, \mathrm{HPO}_{4}^{=}$, and $\mathrm{PO}_{4}$.

As calculated from Table VII, $\Delta G^{\circ}(298)$ for complexing the $\mathrm{HPO}_{4}=$ ion with the $\mathrm{Zn}^{+2}$ and $\mathrm{Zn}(\mathrm{OH})_{2}(\mathrm{aq})$ ions is -11.4 and $-4.50 \pm 2.25 \mathrm{~kJ}$, respectively. Thus, hydrolysis does not appreciably shift these phosphatocomplexing equilibria. The highly positive entropy change determined for the latter complexing reaction is indicative of phosphatocomplex stability at elevated temperatures (see Figure 10). Similar behavior was also observed for the $\mathrm{Cu}(\mathrm{OH})_{2}\left(\mathrm{HPO}_{4}\right)=$ phosphatocomplexing reaction. $(10)$

The presence of an additional $\mathrm{Zn}$ (II) ion phosphatocomplex, $\mathrm{Zn}(\mathrm{OH})_{3}\left(\mathrm{H}_{2} \mathrm{PO}_{4}\right)=$, was indicated at lower temperatures. $\Delta \mathrm{G}^{\circ}(298)$ values for forming $\mathrm{H}_{2} \mathrm{PO}_{4}^{-}$ion complexes with the $\mathrm{Zn}^{+2}$ and $\mathrm{Zn}(\mathrm{OH})_{3}^{-}$ions, however, differ appreciably: -7.1 vs. $-34.9 \pm 2.2 \mathrm{~kJ}$. This result indicates that hydrolysis promotes stability of $\mathrm{Zn}(\mathrm{II})-\mathrm{H}_{2} \mathrm{PO}_{4}^{-}$complexes at low temperatures. The crossover point at which concentrations of the high temperature phosphatocomplex exceed those of the low temperature phosphatocomplex is determined by evaluating the equitibrium:

$$
\mathrm{Zn}(\mathrm{OH})_{2}\left(\mathrm{HPO}_{4}\right)=+\mathrm{H}_{2} \mathrm{O} \mp \mathrm{Zn}(\mathrm{OH})_{3}\left(\mathrm{H}_{2} \mathrm{PO}_{4}\right)=
$$

This equilibrium is independent of phosphate concentration and depends only on temperature; TABLE VII values indicate that the high temperature form dominates above $378 \mathrm{~K}$. 


\section{REFERENCES}

1. C. F. Baes and R. E. Mesmer, The Hydrolys is of Cations, John Wiley \& Sons, New York 1976.

2. I. L. Khodakovskil and A. E. Elkin, Geokhimiya 10, 1490 (1975).

3. A. 0. Gube $1 i$ and J. Ste-Marie, Can. J. Chem. 45, 827 (1967).

4. E. Thilo and I. Schulz, Z, anorg. allg. Chemie, 265, 201 (1951).

5. A-W. Kolsi, A. Erb and W. Freundlich, C. R. Acad. Sci. 282, Ser. C-575 (1976).

6. S. E. Ziemniak, M. E. Jones and K. E. S. Combs, J. Solution Chem. 18, 1133 (1989).

7. H. Ohtaki, T. Yamaguchi and M. Maeda, Bu11. Chem. Soc. Japan 49, 701 (1976)

8. H. Sigel, K. Becker and D. B. McCormick, Biochim. Biophys. Acta 148, 655 (1967).

9. C. W. Childs, Inorg. Chem. 9, 2465 (1970).

10. S. E. Ziemniak, M. E. Jones and K. E. S. Combs, Knolls Atomic Power Laboratory Report, KAPL 4715 (1990).

11. F. H. Sweeton, R. E. Mesmer and C. F. Baes, 1. Solution Chem. 3 , 191 (1974).

12. R. E. Mesmer and C. F. Baes, J. Solution Chem. $\underline{3}, 307$ (1974).

13. N. C. Treloar, Central Electricity Research Laboratory Report RD/L/N 270/73 (1973). (see WAPD-TM-1302, March 1979).

14. W. L. Marshall and E. V. Jones, J. Phys. Chem. 70, 4028 (1966).

15. D. L. Marquardt, J. Soc. Indust. App 1. Math. 2, 431 (1963).

16. P. Schindler, H. Althaus, F. Hofer and W. Minder, Helv. Chim. Acta 48 , 1204 (1965).

17. 0. Kubaschewski and C. B. Alcock, Metallurgical Thermochemistry, Pergamon Press, Oxford (1983).

18. C. M. Criss and J. W. Cobble, J. Amer. Chem. Soc. 86, 5390 (1964).

19. M. H. Abraham and Y. Marcus, J. Chenı. Soc., Faraday Trans. 1, 82, 3255 (1986).

20. D. D. Wagman et a1., J. Phys. Chem. Ref. Data, 11, Supp1. 2 (1982).

21. J. W. Larson, K. G. Zeeb and L. G. Hepler, Can. J. Chem. 60, 2141 (1982). 

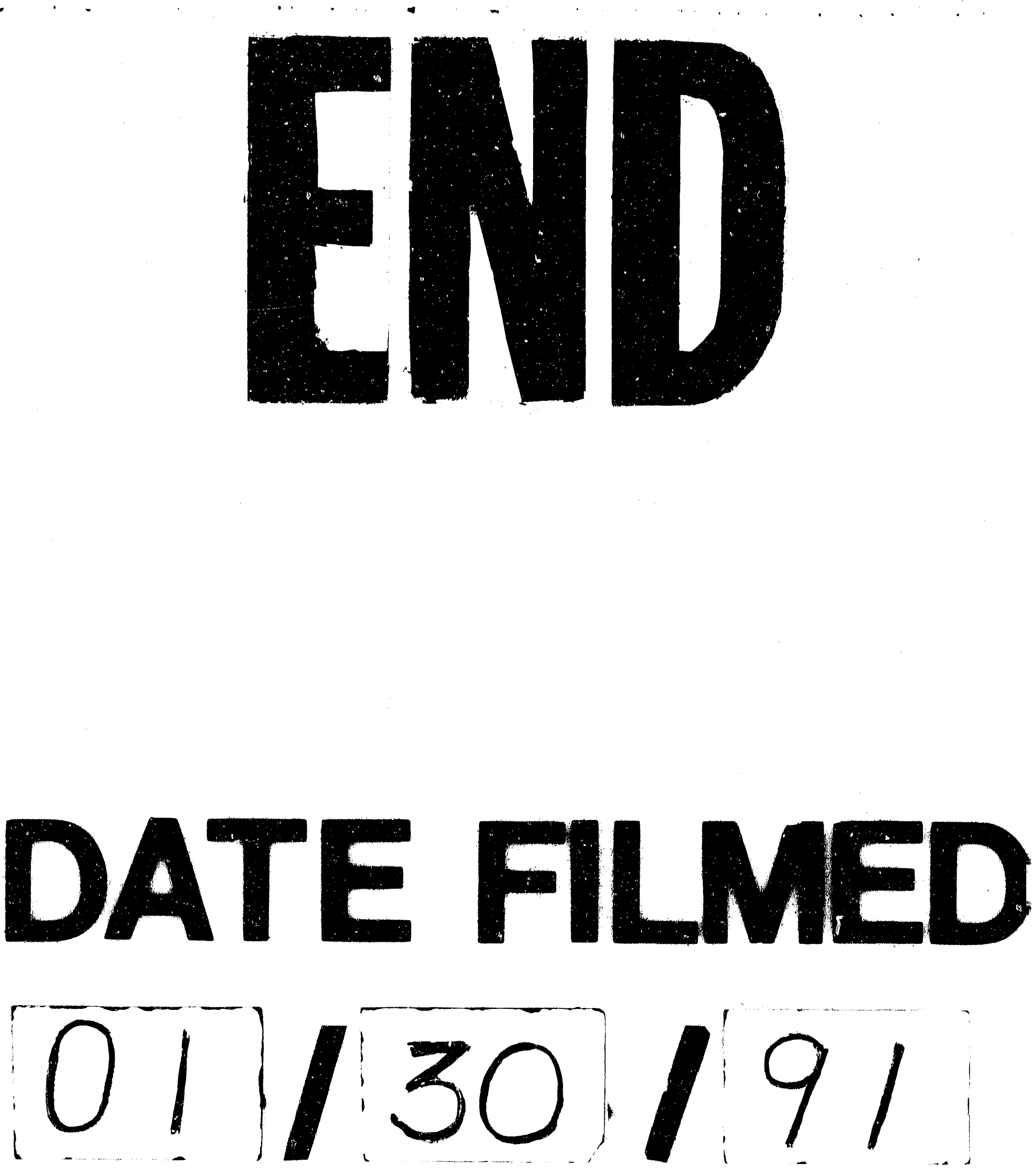
